GAY FATHERS' COPARENTING EXPERIENCES WITH EX-WIVES

\begin{tabular}{c} 
A Dissertation \\
presented to the \\
Faculty of the Graduate School \\
at the University of Missouri \\
In Partial Fulfillment \\
Of the Requirements for the Degree \\
Doctor of Philosophy \\
\hline Dr. Marilyn Coleman, Dissertation Supervisor \\
DECEMBER 2014 \\
bHAM MCCAULLEY
\end{tabular}


The undersigned, appointed by the dean of the Graduate School, have examined the dissertation entitled

\section{GAY FATHERS' COPARENTING EXPERIENCES WITH EX-WIVES}

presented by Graham McCaulley,

a candidate for the degree of doctor of philosophy,

and hereby certify that, in their opinion, it is worthy of acceptance.

Professor Marilyn Coleman

Professor Lawrence Ganong

Professor David Schramm

Professor Mary Jo Neitz

Professor Deborah Finfgeld-Connett 


\section{ACKNOWLEDGEMENTS}

To the men who participated in this study, thank you for sharing experiences, helping with recruitment, and willingness to stay involved with this long study as I followed-up with you. Thank you for participating in this research and making this dissertation possible. I hope you feel the final product accurately reflects your experiences.

To my adviser, Dr. Marilyn Coleman, for the guidance and, most of all, patience you have provided to me over the last decade as you instructed me in scholarship and professional development. Your commitment to mentorship is profound- your door was always open, you tirelessly reviewed dozens of drafts, and you never ceased in challenging me to expand my conceptualizations of this project and social science in general.

To my committee members, Drs. Ganong, Schramm, Neitz, and Finfgeld-Connett, thank you for your time and valuable insights into this project- I am lucky to have had the input of such great researchers. Dr. Neitz, I particularly appreciate your contributions over the years to my development as a feminist. Thank you for FRG and my experiences in WGST. Drs. Ganong and Schramm, thank you for teaching me in the classroom and through my assistantships (and, again, thanks for your patience).

To my colleagues in Extension, Dr. Britt-Ranken, Andrew Zumwalt, Lucy Schrader, and Brenda Procter; thank you for your support in my completion of this project as well as my Extension career. I cannot imagine what it would have been like to meet my family, student, and work demands without such a supportive environment, and 
I am glad to continue my career with you all. Brenda, your mentorship over the years has forever changed the course of my life and led me to where I am today, and I will always be grateful for all you have done for me and my family.

Finally, to my family. Thank you to my parents and siblings for supporting my long student career, especially providing the logistical help and emotional support over the last year of dissertation writing. Thank you for helping with childcare, places to study, and listening to all the dissertation talk. More than anyone, thank you Whitney for always being my partner and taking care of our family during all the late nights and long days I was working on this project (or any of the other projects that led me to finishing this degree). You have given so much to help me finish this, and I could not have done it without you. 


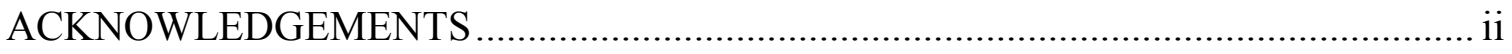

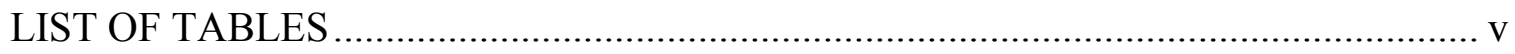

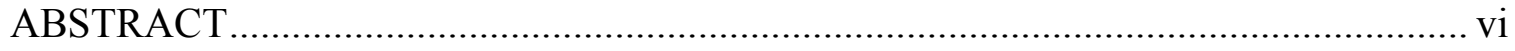

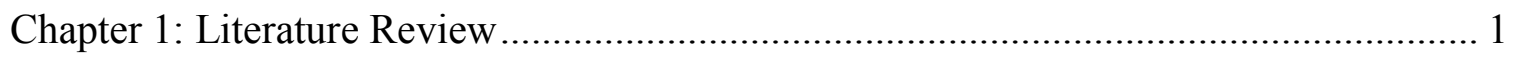

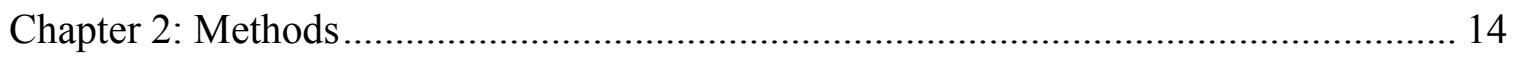

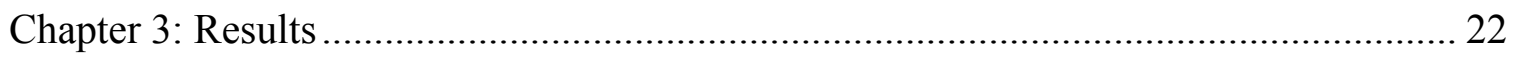

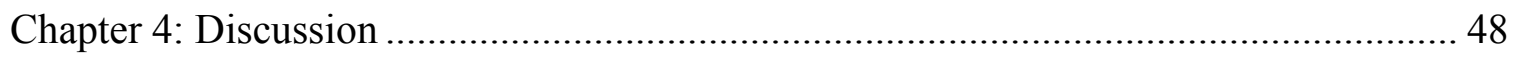

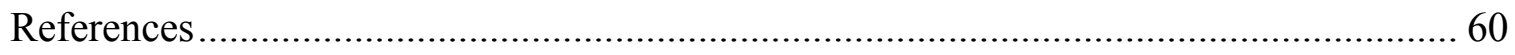

Appendix A. Recruitment Flyer Text ……………………............................................ 69

Appendix B. Initial Recruitment Email ....................................................................... 70

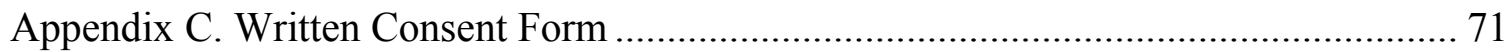

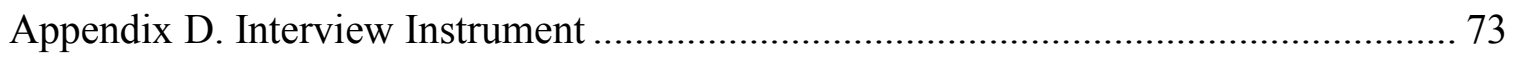

Appendix E. Sample Post-Interview Memo …………………………….................. 77

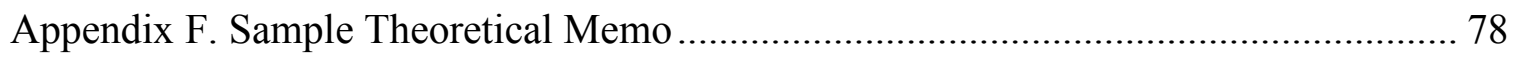

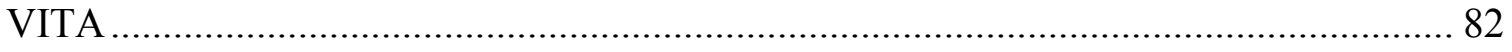


GAY FATHERS' COPARENTING EXPERIENCES WITH EX-WIVES

\section{LIST OF TABLES}

Table

Page

1. Participant characteristics

68 
GAY FATHERS' COPARENTING EXPERIENCES WITH EX-WIVES

\title{
GAY FATHERS' COPARENTING EXPERIENCES WITH EX-WIVES
}

\author{
Graham McCaulley \\ Dr. Marilyn Coleman, Dissertation Supervisor
}

\begin{abstract}
Despite the increasing focus on fathers and coparenting after divorce, little is known about the experiences of gay fathers and virtually nothing is known about their experiences coparenting with their ex-wives. This study examines the post-divorce coparenting experiences of fathers who had children in the context of a heterosexual marriage and later identified as gay. I conducted a grounded theory study of 16 gay fathers who generally described their coparenting experiences as either mostly cooperative or mostly uncooperative. The most salient distinction between the two types of coparenting was father's perceptions of their ex-wives' acceptance of their sexuality. When ex-wives accepted them as gay men and good fathers, coparenting was described as cooperative. When ex-wives expressed religiously-based homonegativity, the fathers described coparenting as uncooperative, and they also reported more adversarial divorce proceedings, more intense anger, and less ability of their ex-wives to move on postdivorce.
\end{abstract}




\section{Chapter 1: Literature Review}

Divorce, especially in families with children, has been a focus of both scholarly and public interest for several decades (Amato, 2010). The first marriage divorce rate has continued to hover around $50 \%$, and approximately $25 \%$ of U.S. children reside in homes with divorced or separated parents (U.S. Census, 2011). The implications of divorcerelated research, therefore, continue to be relevant to a large segment of the population.

Divorce has consistently been associated with children's behavioral, psychological, and academic problems; however, research has also shown substantial variations in children's divorce outcomes (Amato, 2010; Kelly \& Emery, 2003). Researchers have highlighted the importance of parents' post-divorce behaviors on children's outcomes, and the two factors that have appeared to affect children the most have been ongoing interparental conflict and parent-child relationship quality (Amato, 2010; Amato \& Gilberth, 1999; Kelly, 2000). Children seem to do better after divorce when they have close, supportive relationships with nonresident parents (most often fathers; Harper \& Fine, 2006), and the quality of these relationships correlate positively with the quality of the coparenting relationship between fathers and their ex-wives (Carlson, McLanahan, \& Brooks-Gunn, 2008; Sobolewski \& King, 2005; Whiteside \& Becker, 2000). The coparental relationship may be broadly defined as the behaviors and interactions of parents related to their antagonism or support of each other as parents (Adamsons \& Pasley, 2006).

Margolin, Gordis, and John (2001), in a study of married parents, conceptualized coparenting as involving levels of conflict (e.g., hostility surrounding parenting issues), cooperation (e.g., supporting and respecting the other parent, easing parenting burdens), 
and triangulation (e.g., distorting parent-child boundaries in attempts to undermine the other parent). Researchers have presented post-divorce coparenting relationships on a continuum from cooperative to highly conflictual (Ahrons \& Rodgers, 1987). Ahrons (1994) examined the frequency and quality of ex-spouses' interactions and communication (e.g., arguing; conversation quality; accommodations to ex-spouse), and four groups of parents were identified- cooperative colleagues (moderate interaction and high quality communication), perfect pals (high scores on interaction and communication), angry associates (infrequent interaction and moderate quality communication), and fiery foes (low scores on both dimensions).

Similar work by Maccoby and Mnookin (1992) identified three patterns of coparental relationships- cooperative (frequent communication, infrequent arguing, few attempts to undermine other parent, attempts to coordinate consistent rules across households), uncooperative (frequent arguing, challenges of parental authority, attempts to sabotage visits), and disengaged (parents continuing to interact with their child but not with each other). Half the parents in Ahron's (1994) sample had positive coparenting relationships, and although only a quarter of Maccoby and Mnooking's (1992) sample had positive coparenting relationships in the first 6 months after divorce, follow-ups 3 years later showed the proportion of conflictual coparenting relationships had decreased. Generally, the initial 1-2 post-divorce years have been viewed as an adjustment period, oftentimes stressful for parents. Most successfully reorganize coparenting relationships to be less conflictual and more cooperative (Adamsons \& Pasley, 2006), however, conflictual or uncooperative coparenting persists for a minority of divorced partners. 
Although time may be a necessary factor related to the development of coparenting relationship quality, it is seldom a sufficient factor (Bonach, 2005).

Despite increased research on post-divorce coparenting, most of what is known about coparenting has been derived from studies on continuously-married, two-parent families; relatively little is known about what characteristics may shape the quality of post-divorce coparenting relationships in general (Amato, Kane, \& James, 2011; Kamp Dush, Kotila, \& Schoppe-Sullivan, 2011). We do know that divorced heterosexual fathers had better coparental relationships when: (a) mothers supported and encouraged father's involvement in coparenting (Cohen \& Finzi-Dottan, 2005); (b) fathers were more satisfied with their parenting and parenting role (Madden-Derdich \& Leonard, 2002; Olmstead, Futris, \& Pasley, 2009); (c) fathers had less conflict with their ex-spouses; (e) fathers felt more control in child-related decision-making (Leite \& McKenry, 2002); and (f) mothers were more forgiving and less blaming (Bonach \& Sales, 2002).

Bonach (2009) found that parents who were better able to forgive their former spouse's pre-divorce behaviors, as well as parents who felt more positively towards their former spouses, had better coparenting relationships. Overall, it appears that post-divorce coparenting relationships, as well as post-divorce father involvement, may be affected by how former spouses felt about one another before the marriage ended, how they currently feel about each other, how satisfied they are with the divorce proceedings and outcomes, and how well they are able to transition into new post-divorce roles as parents and coparents. Unfortunately, coparenting in diverse family systems has received considerably less attention, and little is known about the post-divorce coparenting experiences of gay fathers who had children in the context of a heterosexual relationship. 
In this study, I examined the post-divorce coparenting relationships of an understudied group, divorced gay fathers with children from heterosexual marriages.

\section{Gay Fathers}

Despite an increasing scholarly focus on fathers (i.e., mainly married or divorced heterosexual fathers), few researchers have examined gay fathers (Benson, Silverstein, \& Auerbach, 2005; Biblarz \& Savci, 2010; Tasker \& Patterson, 2007), and virtually none have examined the coparenting experiences of gay fathers whose children were born in the context of a heterosexual relationship. Gay fathers are perhaps the least studied group of divorced coparents (McHale, Khazan, Erera, Rotman, DeCourcey, \& McConnell, 2002).

As is often the case with stigmatized populations, it has been difficult to accurately estimate how many men are both gay and parents (Golombok \& Tasker, 2010; Lewin, 2009). However, starting in 2000, the U.S. Census allowed respondents to report "unmarried partners" living with them and to identify the sex of these partners. Later versions of the U.S. Census' annual American Community Survey (ACS), as well as the 2010 Census, collected data on same-sex households, including those reporting same-sex unmarried partners or same-sex spouses living with them. These data have suggested that around $20-25 \%$ of same-sex couples are raising children under age 18 in their households (Gates, 2011; Krivickas \& Lofquist, 2011). It is important to note that U.S. Census data only report on gay and lesbian parents who are living with partners and identify themselves in the Census. Parents who are not partnered, do not live with their partners, or choose not to identify their orientation are not counted. 
Fortunately, nationally representative parenthood data have been collected from lesbian, gay, bisexual, transgender, or queer (LGBTQ) individuals, both partnered and single. The 2002 National Survey on Family Growth as well as the 2008 General Social Survey found that about $35-50 \%$ of lesbians and $17-19 \%$ of gay men reported having at least one child. These data are roughly consistent with Census data on same-sex couple households. The recent American Community Survey (ACS) estimates show that the percentage of children in same-sex households is about $14 \%$ for gay couples and $26.5 \%$ for lesbian couples. Although data suggest lesbians are more likely to have children than gay men, both groups are more likely than opposite-sex couples to have a non-related child (e.g., non-biological or adopted child most likely being the child of a partner) in their households (Krivickas \& Lofquist, 2011). It is unknown how many of these "nonrelated" children (e.g., stepchildren) were conceived in the context of a heterosexual marriage. We do know that when one or both partners in a same-sex household report having been married previously, it is more likely that there will be children present in the household (Gates, 2011).

Although same-sex couples are raising children from previous relationships, including children from previous heterosexual marriages, recent trends have suggested a generational shift in pathways to parenthood for gay men as well as lesbian and bisexual individuals. For example, comparative data from the 2000 U.S. Census and the 2009 American Community Survey shows that in the decade between the surveys, the percentage of same-sex couples raising adopted children nearly doubled (i.e., $10 \%$ to 19\%). At the same time, data from surveys such as the General Social Survey indicated that the average age at which self-identifying lesbian, gay, or bisexual individuals have 
their first child is increasing. Taken together, it appears that lesbian, gay, and bisexual individuals may be less likely than in the past to have children early in life with oppositesex partners (Gates, 2011). Instead, they are now having children after they come out through adoption, surrogacy, or reproductive technologies (Patterson \& Riskind, 2010). Given that more gay men are exploring alternatives to heterosexual marriage as routes to parenthood, most of the recent research on gay fathers has focused on those who became fathers after coming out. The main foci of this scholarship have been on how gay couples negotiated the decision to become parents, and how they then parented together (Biblarz \& Savci, 2010).

Traditionally, however, divorced gay men whose children are from a previous heterosexual marriage have been identified as the largest sub-group of gay fathers (Barrett \& Tasker, 2001; Dunne, 2001; Patterson \& Riskind, 2010). A commonly cited estimate has been that approximately $20 \%$ of all gay men have been married to women at least once, although these data are difficult to verify because of samples limited in size and representativeness and the low likelihood that still-married gay fathers would participate in studies of gay men (Buxton, 2001; Ross, 1983). Nonetheless, outside of the recent studies on intentional gay fathers, the bulk of research is on those who were married to women.

\section{Divorced Gay Fathers}

Researchers who study divorced gay fathers have examined why gay men enter into heterosexual marriages and father children, as well as the processes involved with later coming out to spouses, other family members, and children (Armesto, 2002; Benson et al., 2005). Most found that the majority of these men who later identified as gay did 
not enter heterosexual marriages fully cognizant of their homosexuality, although they were aware of some level of same sex attraction (Bozett, 1987; Lynch, 2004). Reasons they gave for getting married included genuine love for their partners, perceptions that marriage was natural or expected (especially for those with more religious upbringings), and a desire for children and family life (Higgins, 2004; Lynch 2004). Those men who were aware of homosexual attractions before marrying also reported marrying because of family and social pressure, notions that marriage might suppress homosexual feelings, or because of perceptions that finding emotionally intimate, stable relationships with other men would be unlikely (Dunne, 2001; Higgins, 2002).

Some gay men married or stayed married, despite some level of awareness of their homosexuality, because of internalized homophobia (usually religiously-based) and a sense of obligation to their wives and children (Dunne, 2001; Higgins, 2004). A changing social climate, however, has led gay men to come out earlier and be less likely to marry women than previously (Patterson \& Riskind, 2010), Although understanding why gay men married women provides context for examining their post-divorce lives, how they managed their coparenting obligations while reconciling their internalized homophobia enough to come out has been understudied.

Religious messages regarding homosexuality have played a role in whether or not, and how, fathers come out. These messages also have influenced the reactions of wives and children to a father's coming out (Pachankis \& Goldfried, 2004). This process can be suppressed by internalized stigma in response to religiously-based homonegativity, and the more religious gay and lesbian individuals were, the higher their levels of internalized stigma (Herek, Gillis, \& Cogan, 2009). Previous research, however, has found that when 
married gay fathers, even highly religious ones, fully accepted homosexual identities, most got divorced, whether by their choice or by the actions of their spouses.

Research on gay fathers who divorced in the 1970s and 1980s found that many men stayed psychologically and emotionally distant from their ex-spouses and their children to avoid rejection (See Armesto, 2002 for review). Although later work (e.g., Benson, Silverstein, \& Auerbach, 2005; Dunne, 2000, 2001) found that the majority of gay fathers shared custody of their children and regularly saw them. Henehan, Rothblum, Solomon, and Balsam (2007), however, found that of the 40 gay fathers in their sample, nearly half did not live with their children and reported that their children never visited them. The authors hypothesized that these arrangements may have been influenced by the homonegativity of their ex-spouses or by the courts not granting them visitation. They concluded that future research should focus on the reasons gay fathers may have little to no contact with their children after divorce.

Research regarding children's responses to their fathers' disclosure of a homosexual identity has been somewhat mixed, ranging from acceptance to anger, although most children reacted positively (Bozett, 1987; Lynch 2004). Garner (2004) found that when a parent comes out as gay or lesbian, children's beliefs about how that parent is viewed are often framed by the heterosexual parent's reaction to the coming out. Children's views may be more negative if the heterosexual parent holds homonegative beliefs.

Mixed results from qualitative work on the reactions of wives have ranged from supportive (including encouraging husbands to continue gay relationships while married) to angry and resentful (including immediately filing for divorce and claiming full legal 
and physical child custody; Barret \& Robinson, 2000; Dunne, 2001). Gochros (1989) investigation of the reactions of wives whose husbands came out as gay found that their process of adjustment involved three phases; 1) an initial period of shock, which often impaired intellectual and social functioning, 2) an interim period of confusion and anger, and 3) a reintegration phase in which the family system adjusted to the change and redefined individual needs and rights. Buxton's (2009) research on the wives and exwives of gay men delineated a similar coping process. Both Buxton and Gochros, to differing degrees, noted that the process can cease or reverse if emotions at any stage are not managed constructively, and that community contexts, such as messages from religious institutions, often played a large role in how wives reacted. As valuable as their work was to understanding the perspectives of wives and ex-wives of gay men, it primarily focused on women's personal crisis and coping processes, with little attention to the implications for post-divorce coparenting.

Dunne's $(2000,2001)$ examination of the experiences of divorced men who came out as gay while married found, similar to earlier research on wives, that fathers perceived a period of shock and anger on the part of the ex-wives, whether or not they were later accepting of the men's sexuality. Most fathers reported that their relationships improved with time. Half of them referred to their ex-wives in "loving ways," about 20\% assessed their relationship with ex-wives as "ok," 5\% felt the relationship was strained, and $25 \%$ reported that their ex-wives were still angry. The focus of Dunne's study was not on coparenting, however, and included little analysis of the connection between exwives' attitudes towards the fathers and the development of post-divorce coparenting. Dunne did suggest that more amicable relationships with ex-wives translated to fathers' 
greater access to their children. Although this work provided useful information on divorced gay fathers, responses were diverse, and there was little investigation of the processes of post-divorce coparenting.

\section{Gay Father Identities}

Stigma and fathering identities. Gay fathers' post-divorce relationships with children and ex-spouses appear to be influenced by their perceptions of themselves as fathers and by contextual factors such as support or homophobia from courts or exspouses (Armesto, 2002; Lynch \& Murray, 2000). The complexity of gay fatherhood, therefore, is likely best understood as an interaction between internal (i.e., psychological factors) and external influences (i.e., contextual influences; e.g., Coltrane, 2004; Lamb, 2010). Given the social construction of parental identities and the impact of societal expectations on parents, expectations communicated by other parents, family members, and courts may be relevant to fathers' beliefs about appropriate post-divorce parental roles (e.g., Adamsons, 2010; Madden-Derdich \& Leonard, 2002; Markham, Ganong, \& Coleman, 2007). Further, the messages courts communicate about parenthood and fathers' perceptions of satisfaction with those court communications have been found to influence nonresidential father involvement and coparenting interactions for heterosexual fathers (Kruk, 2010).

Although scholars have found gay and lesbian parents to be as effective as heterosexual parents, LGBTQ parents have consistently faced discrimination, particularly concerning child custody (May, 2001). Even though most states currently presume joint physical and legal custody to be in the best interests of children and do not explicitly consider gender as a determinative factor, some states continue to consider a parent's 
sexual orientation in making child custody rulings, and some may presume that a parent's LGBTQ identity will adversely affect children to some degree. LGBTQ parents have also reported experiencing frustrations with institutions such as schools that assume through curriculum and school outreach that all two-parent families are heterosexual (Galvin \& Patrick, 2009).

How stigma perceived from others can affect gay men's identities as fathers and coparents may be explained through symbolic interactionism (Mead, 1934) and its derivative, identity theory (Stryker, 1968). These theoretical frameworks suggest that parents' post-divorce coparent identities and their satisfaction with coparenting involves their determinations of how congruent they believe the attitudes and expectations of others (especially the other coparent) are with their own attitudes and expectations for post-divorce coparenting. If fathers feel confident as parents and believe the coparenting relationship is important, then they are more satisfied with coparenting when their exwives, other family members, and community members are supportive of them as fathers and coparents (Adamsons \& Pasley, 2006).

Although some researchers have found that divorced gay fathers felt confident about their parenting abilities, their confidence and parenting satisfaction was, nonetheless, affected by both external (e.g., from courts) and internal (e.g., their own conceptualizations of fatherhood) stigma (e.g., Armesto, 2002; Benson et al., 2005; Bigner \& Jacobson, 1989a, b; Lynch \& Murray, 2000). Societal expectations shape parental identities in different ways (e.g., men as providers and women as nurturers; Adamsons, 2010), and parents are influenced by these expectations and are often active participants in creating gendered parental role identities (e.g., "doing gender;" West \& 
Zimmerman, 1987). Benson et al. (2005) studied fathers whose children were conceived in the context of a heterosexual marriage before they came out as gay, and their findings delineated a process in which these fathers reconstructed the fathering role. The men had been socialized with traditional gender role ideology, which viewed fatherhood at the core of masculinity; being gay was viewed as an antithesis to masculinity. In an effort to conform to this ideology, the men had denied their gay identity and married women. Later, as they more fully realized their gay identities, most were able to reconceptualize fatherhood so that being gay and being a father were complementary rather than mutually exclusive. The ideology they eventually adopted rejected the notion that sexual orientation defined whether or not one can be a competent father and instead placed importance on fathers' relationships with their children (Benson et al., 2005). Divorced gay fathers from earlier decades appeared (e.g., Bozett, 1987) to have had more difficulty adopting this ideology than the fathers in Benson et al.'s (2005) study. All divorced gay fathers, to varying degrees, have faced difficulty integrating the identities of father and gay man, which has been suggested as the chief task for gay fathers (Armesto, 2002).

\section{The Current Study}

The purpose of this study was to investigate the process of post-divorce coparenting by gay fathers and their heterosexual ex-spouses. A secondary purpose was to explore the contexts in which gay divorced fathers coparent. Researchers have previously looked at the overall marital relationship history for divorced gay fathers and examined the development of divorced gay fathers' post-divorce parent identities (Benson et al., 2005; Dunne, 2001). This study expands that research by examining the coparenting relationship between gay fathers and their former heterosexual spouses from 
the gay father's perspective. The goal was to identify the ways in which divorced gay fathers develop and maintain coparenting relationships after divorce as well as what may influence these processes. My approach to designing this study involved a theoretical sensitivity to the literature regarding divorce, coparenting, and gay fathers, including sensitivity to how contextual influences and fathers' perceptions may impact coparenting quality. It appears that perceptions of support and relationships with ex-spouses affect how some men relate to their ex-spouses as coparents after divorce, and gay men's coparenting may involve additional factors due to the social context around their sexuality.

Studying which factors may contribute to positive post-divorce coparenting relationships is important for several reasons- positive coparenting relationships contribute to better relationships between nonresident parents (usually fathers) and children (Carlson, McLanahan, \& Brooks-Gunn, 2008), children do better when they have close, supportive relationships with fathers after divorce (Amato \&Gilbreth, 1999; Carlson, 2006; Harper \& Fine, 2006; King \& Sobolewski, 2006), and positive coparenting relationships, in general, contribute to better post-divorce outcomes for children (Sandler, Miles, Cookston, \& Braver, 2008). It is also important to learn about these unique experiences to inform those who work with gay fathers and their children, especially since so little is known about post-divorce coparenting experiences of gay men who experienced heterosexual marriages. Findings related to the processes of divorced gay men integrating their gay and father identities, as well as developing positive postdivorce coparenting relationships, may be beneficial to those in similar situations to the fathers in this study. 


\section{Chapter 2: Methods}

In this study I employed grounded theory methods (i.e., Corbin \& Strauss, 2008), which are appropriate to use in an area in which limited research has been done (Creswell, 2007). Grounded theory methods are appropriate tools to use when research questions are about processes (Richards \& Morse, 2006). The dynamics of post-divorce coparenting by gay fathers and their ex-wives (i.e., how coparenting relationships are developed and maintained) were the processes examined in this study. Coparenting relationships among gay fathers and their ex-wives have not previously been directly addressed in the literature.

\section{Recruitment}

Gay fathers were recruited through a combination of convenience sampling (e.g., contacting fathers who had participated in two previous studies), snowball sampling (e.g., asking participants to identify other gay divorced men who were coparenting with a heterosexual ex-wife), and announcements posted online. My first contact was a gay father I originally interviewed for another study on post-divorce coparenting, which was not designed to examine experiences of gay men. I asked him to share information about my study with other divorced gay fathers who might agree to be interviewed. The same request was made to each father after interview completion. Half of the sample $(n=8)$ were recruited by snowball sampling.

Four fathers were recruited in response to a flyer posted on Facebook (see Appendix A). This online recruitment flyer also attracted the attention of an author of a book on gay fathers who agreed to forward information about my study to fathers he had 
interviewed for his book. This contact accounted for the recruitment of another four fathers.

\section{Sample Description}

The final sample consisted of 16 men who currently identified as gay and had children from a previous heterosexual marriage. Given the somewhat narrow parameters of these criteria, no additional limits were placed (e.g., age range, marriage length, child custody arrangement, current relationship status). The average age of the sample was 46.00 years, average number of years married was 14.22 years, average age of all children was 17.65 years, and the average time since divorce or separation from ex-wives was 9.10 years. All were White, middle- to upper-socioeconomic status, and from Christian backgrounds. Table 1 contains demographic information for each father. All the men were given pseudonyms to protect their identities.

Fourteen fathers were legally divorced from their former spouses, and two were separated but not legally divorced. The two who were separated lived apart from their exwives (and dated men) but, because they had not felt the need to do so, had not legally divorced. These fathers anticipated they would do so at some point, maintained a separate household from their ex-wives, and had to negotiate many of the same financial and custody arrangements as those who had legally divorced; therefore, for parsimony their separations are implicated when "divorce" is used in this paper.

Most of the fathers $(n=14)$ had been married only once to a woman; two had been married to women twice. One father had been in a brief, childless marriage before marrying the woman with whom he had children. The remaining father, after ending a union that produced children, remarried a woman who knew he was bisexual (at the time 
of their marriage). Their marriage did not produce children, and they eventually divorced. He now identifies as gay rather than bisexual. Overall, 11 of the fathers were partnered with men (i.e., exclusive dating relationship, cohabiting, committed partnership, or marriage) at the time of the interviews. The other five fathers had previously been in relationships with men but were not dating at the time of the interview. Although the men in the sample now reside in multiple settings (i.e., urban, suburban, and rural; 11 in Missouri, 4 in other states, 1 in London), 13 fathers grew up in rural communities ranging in population from several hundred to under 25,000 , and three grew up in suburban communities with populations under 100,000.

\section{Interview Procedures}

Once fathers contacted me, I sent them a recruitment email (see Appendix B) that provided a brief description of the study. Fathers willing to be interviewed emailed or called me to schedule an approximately 90-minute interview. All but three fathers who contacted me were interviewed (the ones who were not interviewed either later declined participation or were ultimately unable to schedule an interview). Those living or working in the Columbia, MO area were invited to meet in a private setting on the University of Missouri campus $(n=3)$ or their home $(n=1)$ for a face-to-face interview. The rest of the sample, due to geographic distance, work and schedule demands, or general preference, were interviewed by phone $(n=11)$ or Skype $(n=1)$. All interviews were digitally recorded and transcribed verbatim.

Interviews began with informed consent (see Appendix C). Face-to-face interviews proceeded after the fathers gave written consent. Telephone and Skype interviews proceeded following verbal consent. The interview protocol contained guiding 
questions developed from the literature to generate information about the fathers' postdivorce coparenting relationships (see Appendix D). The interview format was semistructured, and fathers were asked about their marriages as well as their experiences before and after marriage. Initial interviews ranged from 1 to 2.5 hours, with the average length being about 90 minutes. After completing each initial interview, I digitally recorded a post-interview memo to capture my initial impressions. In these memos I commented on the content of the father's interview and generated hypothesizes regarding his story. As I interviewed more fathers, I also began to reflect on how each father's interview may be related to emerging categories and other ideas that I was generating (see Appendix E for a sample memo). In memos, I compared each interview with observations from earlier interviews- what was similar, what was different, and I noted issues or phenomena to be sensitive to in future interviews.

As the study progressed, I modified the interview questions in order to investigate concepts that I thought might be important. For example, the influence of religious beliefs on the fathers' coparenting stories began to be more apparent later in data collection and analysis so I added questions about religious background and training. If fathers from earlier interviews had not been asked particular questions on topics that emerged as relevant in later interviews, I contacted them for follow-up interviews. As I reread and coded transcripts, I eventually interviewed all the fathers in the sample a second time to explore issues further (e.g., asking more questions about their perceptions of certain aspects of their coparenting relationships). Some follow-ups interviews were in-depth (e.g., 45-60 minute phone calls to probe parts of fathers' earlier interviews) and some were brief (e.g., 1-2 questions through email or Facebook chat). For example, 
although all the fathers had talked at length in earlier interviews about how satisfied they were with their coparenting relationships, a few had not rated their satisfaction with the relationship in the initial interviews (which was a later-added question that was asked towards the end of interviews). For those who had not been asked to rate their satisfaction in the interviews, their ratings (along with comments) were retrieved via email or chat. I continued interviewing, coding, analyzing data, following up, and reviewing memos, until I felt that collecting new data did not generate new information (i.e., theoretical saturation; Corbin \& Strauss, 2008).

\section{Data Analysis}

All interviews and memos were loaded into Dedoose qualitative research software. Dedoose was used as an organizational tool that allowed me to assign codes to text; merge codes, create categories and subcategories; and easily view all data within these categories. The first step to identifying categories within the data was line-by-line coding (i.e., open coding; Corbin \& Strauss, 2008). I wanted any theory to come directly from the data (e.g., inductive approach), so I tried not to code too narrowly. I coded each line as I did not initially know what concepts would eventually prove germane to theory construction. In this initial stage, I "broke apart" the data by identifying concepts in the text. As I identified concepts, I compared data from new transcripts to already coded data (e.g., constant comparison method; Corbin \& Strauss, 2008) and when data appeared to represent a concept or description of phenomena unique from what had been coded, I created a new code. When new data fit within an existing code, either that code was applied or a subcategory of the code was created. 
Throughout the coding process I created theoretical memos (e.g., written records of analysis; see Appendix F), which also helped me to pull back from the line-by-line detail of analysis and begin to see the themes in the data. Whereas my earlier postinterview memos were focused on understanding an individual's story, the theoretical memos were more focused on examining themes across participants' stories. Theoretical memos became another source of data to be used in the constant comparison method.

As I reconceptualized the data (which had been "broken apart" during open coding), similar codes were combined or grouped into categories. I moved from describing phenomena (e.g., different parts of the fathers' stories) to building theoretical explanations (e.g., explaining processes in post-divorce coparenting). This not only involved thinking in more conceptual terms, but examining and comparing codes to conceptualize how they may relate to one another. (i.e., axial coding; Corbin \& Strauss, 2008). For example, I identified several codes that described how fathers explored their sexuality while married and before coming out, including "gay porn," "gay chat lines," "internet contacts," "fantasizing about men," and "hook-ups." I collapsed these codes into a larger concept titled "gayness in marriage," as these activities were used by fathers to cope with the dichotomy of having a (often emerging) gay identification while in a heterosexual marriage. This method of comparing emerging categories with new data helped me begin to see patterns in the data and determine which categories were substantiated and which appeared less relevant.

I looked at the range of experiences represented in the categories and how these categories fit together to tell a larger story of post-divorce coparenting for these gay fathers (Corbin \& Strauss, 2008). For example, categories such as "valuing of fatherhood 
role," "changes in coparenting relationship," "forgiveness," "processing of divorce," "reaction to new partner," "views on father's gayness," "current relation to ex-wife," "change in communication," and "religiously-based homonegativity" (i.e., axial codes) were combined into the more theoretical category of "perceptions of acceptance" to describe the fathers' overall perceptions of acceptance from their ex-wives as gay men and coparents and the factors involved in these assessments (i.e., selective coding; Corbin \& Strauss, 2008).

I then examined under what conditions, and with what consequences, the larger conceptual categories occurred. In this final stage of selective coding, the core category (the main theme) was solidified. The fathers' perceptions of their ex-wives' acceptance of them as gay men and fathers appeared to have the most explanatory relevance and potential for linking together the other categories. I continued to organize my data more abstractly to unify other categories around the core category, including clarifying how the coming out process unfolded, how fathers' satisfaction with the divorce affected their perceptions of acceptance, and how these perceptions influenced the coparenting relationship. This led to the creation of the three main conclusions of this study, which are presented in the results to contextualize them as part of the storyline (Corbin \& Strauss, 2008) for the fathers' experiences. These conclusions represent the culminations of findings that were fully substantiated in the data. Although fathers' experiences occurred along a range for each finding, the main conclusions fit within all their stories without exceptions. These saturated categories also held the most explanatory power related to gay fathers coparenting processes. 
Although other categories emerged through data analysis, isolated findings, unlinked lines of argument, and findings not representative of all the fathers' experiences were not reported (e.g., Finfgeld-Connett, 2014). Overall, saturation and validity in the creation of conclusions involved the analytical process of moving from detailed, line-byline coding to a more conceptual coding scheme, regularly reading and rereading transcripts, constantly comparing codes, categories, and themes through theoretically memoing; staying in touch with participants to get feedback on emerging concepts; and getting guidance and feedback from my dissertation advisor. 


\section{Chapter 3: Results}

The primary focus of my study was the post-divorce coparenting relationships of gay fathers. Aspects of the fathers' stories that reflected actions and interactions commonly defined as coparenting (e.g., coparental communication; coparenting behaviors) were examined along with their comments on overall satisfaction with coparenting. Fathers' stories about their post-divorce coparenting experiences tended to be dichotomous in nature. That is, they generally described their coparenting experiences as either mostly cooperative or mostly uncooperative, and the chief and most salient distinction between the two types of coparenting was father's perceptions of their exwives' acceptance of their sexuality. The fathers' perceptions of their ex-wives' acceptance of their gay identity generally began when they first came out. For most $(n=12)$, this was prior to divorce, and the ex-wives' initial reactions set the tone for how the divorce process and the coparenting relationship unfolded. No fathers described the coming out process as easy, and all reported that their wives were angry, sad, confused, and felt betrayed. Those who felt more accepted $(n=9)$, however, reported that their exwives did not express religiously-based homonegativity. They felt that their ex-wives' anger was largely resolved after a 1-2 year transition period and had had little or no impact on coparenting quality. These fathers felt their ex-wives treated them as fully participating coparents, which in turn influenced their coparenting satisfaction. On the other hand, fathers who felt that their ex-wives believed that expressing a gay identity was immoral and involved choice did not feel accepted $(n=7)$ and reported more adversarial divorce proceedings, more intense anger, and less ability of their ex-wives to move on post-divorce; all of which negatively affected coparenting quality. Thus, the 
core theoretical concept was ex-wives' acceptance of fathers' homosexuality, and three main conclusions were found related to fathers' perceptions of ex-wives' acceptance, their coparenting relationships, and the role of religiously-based homonegativity.

\section{The Coming Out Process}

Background. A range of pre-marriage experiences were reported by the fathers, but a commonality in their stories was of early sexuality and gay identity suppression. Most fathers described beginning to feel different around middle childhood (e.g., more interested in the male lead in movies versus the female, crushes on male peers, desires to hug or cuddle other boys, overall feeling different from their male peer group). As teenagers they could clearly identify same-sex attractions. Some identified internally as gay or bisexual, although most were confused and believed that homosexuality was wrong, at least for them. These men were from conservative backgrounds, and many were quite religious. Most reported that religion influenced their beliefs that homosexuality was immoral (i.e., religiously-based homonegativity), and these messages were communicated both implicitly (e.g., "It's just the Bible Belt normalcy here." Frank) and explicitly (e.g., "I remember going on a student [church] retreat and talking about worrying I was gay, and they actually tried to do an exorcism to cast out sins." Bill).

Only two fathers did not report specific religious experiences that led them to suppress their sexuality, but these two, like the rest of the fathers, felt conservative social climates, arguably influenced by religion, led them to suppress their gay feelings (e.g., "I grew up thinking it wasn't normal...not really a religious influence but more just a small town upbringing which instilled those type of values."-Gentry). Some of the father's 
families of origin explicitly condemned homosexuality; others did not discuss it, but none were from environments where exploring sexuality was communicated as appropriate. Based on the social, familial, and religious climates they experienced in early adulthood, coming out and living as a gay man was not seen as an option, much less a path to fatherhood and family life.

It was sort of a triple whammy, because compounded with the cultural disapproval and disapproval from probably most of my family, was the theological guilt that I felt as well. . I did not want to be gay... I thought if I married I could fix myself. -William

There was much similarity in the fathers' stories of their early feelings of gayness, and the decision to not explore their sexuality, which informed conclusion one: When gay men grow up in more conservative social environments, they are less likely to accept their gay identity and more likely to suppress it. Stories regarding the logic for marriage were also similar across the sample. The same pressures that influenced the men to deny or not explore being gay also shaped their decisions to marry. All, however, said that they were in love with their ex-wives when they made the decision to marry.

I knew that I wanted to be a dad. But I did not even fathom that there were gonna be any other options to have a child other than getting married, what I thought was the natural way to go. I did love [ex-wife]. She was my best friend, so it made sense to me. I also believed this idea, that with enough God and enough family I could change. - Tom

Some truly believed they were mostly straight when they got married, some thought they might have been bisexual, but most were aware they were gay and believed 
that by marrying women, as RR put it, the "feelings would follow the actions." Overall, their decisions involved: (a) a genuine caring and affection for their now ex-wives; (b) a desire to be normal and compliant; and, above all else, (c) wanting a family. All of the fathers intentionally had children within a few years of marriage, and all reported embracing fatherhood enthusiastically. They described themselves as being more involved with their children than what they perceived the average father to have been, and they generally described their fatherhood role as central to their identity during the marriage (e.g., "I was the oddball dad who took his kids to the park during the week with the other moms... I was more active than the typical dad, and I really cherish that." -RR). At some point during their marriages, however, the fathers began to more fully realize their sexuality and could no longer suppress their gay identity. The internal coming out process unfolded over many years.

Coming out to self. As their marriages continued, all of the fathers began to explore their sexuality privately, usually by viewing gay pornography or using gay chat lines and internet sites, with the exception of one father who reported that he limited his gay activity to his dreams. Seventy-five percent of the fathers reported physical contact with other men during the marriage, although aside from three fathers who entered into gay relationships in the final months of their marriages before divorcing, sexual relations with other men during marriage were largely brief, isolated encounters (e.g., hookups). Those who explored a gay orientation, either physically or mentally, often felt intensely guilty, and they continued to view homosexuality as wrong. They also felt guilty because they believed that extramarital relations or a non-heterosexual orientation conflicted with their roles as husbands and fathers. 
Within four years of marriage, I knew that it was going to be a problem that was going to rear its ugly head. I was constantly thinking about men, but I thought "I've gotta do everything I can to deal with it" because it would be very devastating... With each successive year it just became more and more difficult. $\mathrm{RR}$

As the fathers more fully accepted that they were gay, they slowly overcame internalized religiously-based homonegativity and cultural stigma. Their guilt associated with gayness as immoral or wrong began to dissipate first, but their guilt associated with gayness conflicting with their husband and fatherhood roles often persisted:

I'd been struggling with my sexuality and with church and faith, and my faith was really beginning to crumble, so that might have been one of the reasons I[eventually] realized my identity... I suppose I went through something of a life crisis. I thought I can't cope with carrying on being married, but on the other hand I can't cope with the idea of letting the kids down. -Bill

Coming out to wives. The time period between fathers more fully coming out to themselves but not to their wives was described as stressful and often depressing (e.g., “My health started to deteriorate mentally, and I became depressed. I just knew I couldn't keep a foot on both sides of the fence and maintain any sense of stability."-Truman). When they came out, fathers reported that their ex-wives initially expressed varying levels of sadness and anger as their gayness and the eventual need to divorce became more certain. These feelings were present regardless of how the men initially presented their gayness to their wives (e.g., as gay, bisexual, or questioning) or whether they intentionally came out or were caught by their ex-wives (e.g., engaging in gay online 
activity). Fathers who came out to their wives while married did so in three different ways, either as bisexual or questioning $(n=2)$, gay $(n=5)$, or as intending to repress their gay/bisexual identity through religious counseling (e.g., reparative therapy; $n=5$ ).

Fathers' perceptions of their ex-wives' views on homosexuality affected the coming out process as well as how accepted they felt. For example, Frank's ex-wife's attitude towards homosexuality initiated his own coming out process and did not complicate the process of separating.

I was in denial [about fully being gay]... I wanted to make it work for our child's sake, which in the long run would never have worked. She was more accepting of it because around the time we separated her father passed away, and she found out that he had been gay but was hiding it. So she said to me "You know what? If you're gay, I'm fine with that. Just tell me the truth." I was relieved because, you know, I had been unhappy. She was unhappy too and in a way was relieved, but then again, kind of in grief. [But] we both hoped to provide stability for [son], making sure that he gets what he needs to grow up to be a wonderful adult... We pretty much agreed on a lot of stuff beforehand so [the divorce] wouldn't get ugly, and it was pretty straightforward. -Frank

Fathers who did not believe that their ex-wives held homonegative views were more likely to come out as gay without intentions of repressing their sexuality. The five who felt the need to come out as fully gay presented their sexuality with considerably more certainty than those who defined themselves as bisexual, questioning, or intending to deny their gayness through religious instruction. They also divorced more quickly than 
the other fathers and for all but 1 of these 5, their ex-wives' general acceptance of homosexuality eased the divorce transition period.

She was mad about how she was going to deal with the situation [divorce], but there were no disparaging remarks about being gay. I think that she realized pretty quickly that I was in a lot of pain because I'd been trying to repress this, and I think she's a compassionate person, and she had an open mind. I would say within a year it calmed down and normalized, and it [anger] was never to the point where I couldn't deal with it. $-\mathrm{RR}$

The two fathers who first presented themselves to their ex-wives as bisexual or questioning their sexuality reflected that they were not initially ready to fully come out as gay. After non-religiously-based counseling and interacting with other gay men (e.g., friends, support groups), however, they became prepared to fully come out. When they did, similar to the fathers who initially came out as fully gay, they believed that their wives were accepting and that their wives' lack of religiously-based homonegativity fostered more cooperative coparenting.

The five fathers who initially resolved to suppress or eliminate their gayness entered religious counseling or reparative therapy with the intention of living the rest of their lives as married heterosexual men. These fathers had more religiously conservative backgrounds and believed their wives would not accept their homosexuality. Three entered reparative therapy for a few months and felt the decision to do so was primarily driven by religiously-based homonegativity that resulted in their ex-wives contacting church pastors and enlisting reparative therapies. Before long they concluded that they needed to live as gay men and could not continue their marriages. They felt their ex- 
wives did not arrive at the same conclusions, however (e.g., "She just really didn't understand it. She thought it was a choice... She had to believe that to get through [the divorce], and she really went to her faith and got pretty darn close to being a fundamentalist Christian."-Matt).

The other two fathers who attempted to "pray the gay away" felt more agency in their decisions to suppress their gayness and remained married for several years after their initial disclosures to ex-wives. Nipper, who remained married for 11 years after he came out, eventually accepted his gay identity and reconciled his religious views on gayness, and felt more congruence with his ex-wife than the other fathers did. Although both had been heavily involved in a Southern Baptist-based church that condemned homosexuality, after years of reparative therapy they came to similar conclusions about his gayness. Nipper felt his ex-wife was still angry over their marriage ending, but her lack of religiously-based homonegativity made for a more cooperative divorce process. When I told her that I just couldn't do this anymore; that I had to get out of the marriage and live my life as a gay man... I think on some levels she understood it wasn't something that I wanted or asked for, and she did understand that I tried reparative therapy for seven years and spent another three years [in marriage and attending church] after that to make it work, I just didn't walk away, that I tried hard. So I think she understood that... and she's actually [now] very progressive on the gay issue. The anger [when divorcing] came from the view that our family was not gonna be the same dynamic. But I do give her credit; we had a very amicable divorce and custody agreement. [And] early on she said "You are a great 
dad. I may stay mad at you for a long time, but the boys are not gonna pay that price. -Nipper

Similarly, Tom and his ex-wife initially conceptualized the implications of his sexuality similarly (i.e., as wrong), but over time their views became less congruent and caused strife.

As time progressed, I finally came to the conclusion that being gay isn't being broken, and I don't need to be fixed. She then pushed even harder. For her it was a struggle because she couldn't change her fight. For those five years that we tried to work it out together, there was nothing she could do to change the situation... So she was defeated, and I think that pissed her off. Her only competition was using guilt and God to try to change the situation. One of the struggles in all of this is that while we're both Christians, she and I have very different views [on] being gay as being a sin. I feel like [paying irrevocable spousal maintenance to ex-wife] was blood money- it was my payment for guilt and now she feels like it's owed to her. She doesn't care what happens to me.Tom

Comparing Nipper and Tom's experiences in coming out to their ex-wives shows how religiously-based homonegativity affected their ex-wives' reactions and also highlights how parents' differing views can impact the final stages of coming out and the resulting divorce process.

\section{The Divorce Process}

After coming out, 5 fathers remained married for a period of years $(\bar{X}=6.25$ years), while 7 divorced within a matter of months ( $\bar{X}=4.83$ months). No matter how 
long they remained married after coming out, the divorce process seemed to differ depending on how much anger the fathers perceived from their ex-wives. Stories about the process could be characterized as amicable (e.g., short, little to no disagreement on child custody and division of property, little attorney or court intervention), mediocre (e.g., a brief period at the start of the process where parents were not in agreement, but generally straightforward with little attorney or court intervention), or antagonistic (e.g., adversarial, drawn out, heavy use of attorneys, multiple court appearances).

I considered the two fathers who are still legally married but living separately to also be effectively divorced, and they felt accepted as gay men by their ex-wives and reported agreement on post-separation arrangements (e.g., financial, access to children). Acceptance seemed to go hand-in-hand with amicable or at least relatively low conflict divorces and earlier agreement on parenting plans. This is not to say that some fathers who felt accepted by their ex-wives did not later reflect that they would have done things differently during the legal divorce process. Many felt motivated to take care of their exwives and children when they divorced, often because of guilt. These motivations led to financial decisions such as voluntarily paying spousal support, paying child support additional to that required by the court, or relinquishing claims to marital property. The difference for those who felt their ex-wives accepted them as gay men, compared to those whose ex-wives were unaccepting, was the lower likelihood of making decisions because of conflict with their ex-wives. Their later dissatisfaction over the legal divorce was primarily related to reconsiderations of financial arrangements that subsequently surfaced but did not affect coparenting or involve animosity towards ex-wives. 
On the other hand, most fathers who felt their ex-wives were unaccepting characterized their divorces as antagonistic. They attributed this to perceptions that their ex-wives were attempting to punish them through the divorce process. John reported intense anger from his ex-wife and described a much more adversarial division of assets than RR.

There was no reason she couldn't have come to me and said “Okay, I'm done. We need to financially help each other out here." It wasn't like that. It was "You need to give me everything that you own, and I will give you what I think you deserve." My lawyer was really clear. "You cannot give away this. The issue of material objects has nothing to do with her inability to accept that you're gay," and her advice was to sell it all and divide the money. My ex wouldn't go for that, so we had to divide the properties and stuff, and it was really hard. Her story was one of pure victim and betrayal and making me pay. - John In addition to more antagonistic divorce proceedings overall, the majority of fathers who felt unaccepted also reported that their ex-wives used, or threatened to use, their sexuality against them in the legal divorce process, something that none of the fathers who perceived acceptance reported. Truman reported that his ex-wife communicated religiously-based homonegative views about him to his children, and he also felt that she focused on his gayness in their conflictual divorce proceedings.

She wanted sole custody. I was suddenly less than human and not fit to be around the children I once took care of solely (laughs). It [father's sexuality] became a highlight of it [divorce proceedings] rather than the fact that the relationship was over. Her attorney was a homophobe, and she was, too... Rather than focusing on 
the fact that the relationship was irreparable, it became the fact that I was following a whim...That I would be a bad influence on the children. There were threats that if we went to trial there would be character witnesses that would speak against me. They were threatening to use the children, and I just wasn't gonna do that to them.... basically my attorney and I just decided that it [conceding on unequal division of assets and less time with children] was the price that we would pay for the freedom. -Truman

Ex-wives with greater homonegativity and anger were more likely to introduce gay prejudice clauses (e.g., paramour clauses or other additions the fathers felt were driven by their sexuality) in the preparation of divorce decrees or parenting plans. This presented an additional element of conflict in the process that all but one of the fathers who felt unaccepted reported. These fathers felt their ex-wives attempted to build a case against them by suggesting their gayness contributed to an unsuitable environment for children. The results reported here of the 12 men who came out before divorcing are similar to those of the 4 who came out after the initial divorce was finalized, in that motions to modify custody orders can be thought of as a continuation of the legal divorce process. Two of these fathers felt accepted by their ex-wives and did not return to court. The two who did not feel accepted felt their sexuality was used against them by their exwives.

The use of an adversarial approach in divorce proceedings contributed to fathers' feelings of dissatisfaction with the process and the development of the post-divorce coparental relationship. Fathers' perceptions of coparenting quality often drew on a history of their ex-wives' attitudes towards their gayness. The fathers highlighted the 
importance for their children and the coparenting relationships of their ex-wives being able to set aside or process their anger related to the divorce and the coming out process. Many fathers who said their ex-wives could not do that continued to view their ex-wives as vindictive and unreasonable.

\section{Post-Divorce Coparenting}

A range of post-divorce coparenting experiences were reported, and most fathers could identify both positive and negative aspects of their coparenting relationships. The most salient categories, in addition to ex-wives' acceptance of them as gay men, were coparental communication, coparenting behaviors (e.g., decision-making, support, undermining), and overall satisfaction with the post-divorce coparenting relationship (see Appendix $G$ for a table of codes that summarize the conceptualization of coparenting quality).

Coparental communication. The fathers who felt accepted were satisfied with coparental communication and described fairly cooperative coparenting interactions. Some $(n=3)$ talked almost daily and even spent time with their ex-wives and children together in the family home; others had less integrated coparenting relationships (e.g., occasional brief email or text message check-ins on child-related issues). Regardless of frequency or method, most communication was positive. None of the fathers who felt accepted reported communication problems due to ongoing frustrations with the other parent, nor did they perceive difficulty in dealing with their ex-wives. Their descriptions of cooperative communication included keeping one another informed of child-related issues (e.g., "When it comes to school, we copy one another on emails or we give each other a call or shoot each other a text saying what we're doing, just out of respect." - 
Kent) and each parent making efforts to involve the other in parenting decisions (e.g., "Anything around the kids is a joint thing... It can be difficult at times [to parent disabled son], but we talk about it together." -Bill).

By the time of the interviews, all of the fathers had accepted that they were gay, and how they perceived their ex-wives felt about this influenced their descriptions of communication (e.g., “Communication isn't great; I'm still defensive over her trying to make me out as a bad person because I'm gay. I don't think it's going to get better until I hear 'I know you're gay, and it's okay". She doesn't call me an abomination anymore, but I can see it in her face." -Chris). Fathers whose ex-wives rejected their gayness shared stories of negative communication, often characterized as conflictual and being treated unfairly or aggressively. By the time of the interviews most had made deliberate attempts to avoid this. (e.g., "I try to interact with her as little as possible because most of the time she's really unpleasant" -Truman). Conflictual interactions were frequently tied to stories of children being involved. For example, Truman was unable to establish a visitation schedule with his ex-wife (or adhere to their parenting plan).

Suddenly I'm a monster, and she would tell me when I could or couldn't see the kids. I'd say "Hey, how about I come over and take [daughter] to dinner," and if she responded to me at all it'd be "She's busy". She [also] put my daughter in the mix of it. Recently she [daughter] was texting me "I just want to come over for the day, I don't want to spend the night," and then she got in the car and said "I'm sorry, I didn't mean that." I think she felt like she was in the position that she had to let her mother know she wasn't excited to come be with her dad, but when she was with me she was excited. That's just horrible for a child. -Truman 
Coparenting Behaviors. Fathers who felt accepted as gay men felt their ex-wives valued their roles in the children's lives. Coparenting behaviors reported by these fathers were mainly cooperative, such as joint decision-making (e.g., "She doesn't make decisions for [daughter] without me" -Mike); structuring interactions with the other parent to prioritize the children's well-being (e.g., "We're both committed to have the best outcome for our children" -RR), setting aside personal problems (e.g., "We set aside so much animosity to talk about [son's academics]" -John) and not badmouthing the other parent to children (e.g., "There were times I know she had to bite her tongue and not say anything at all, but she never badmouthed me in front of the boys" -Nipper); and overall being supportive of one another as coparents (e.g., "We're willing to have the same position on things...if one of us tells them something, we stand together on that" Bill).

The fathers who felt less accepted, however, reported more difficulties with joint decision-making. Some felt excluded when decisions were made primarily by ex-wives, while others were frustrated by a lack of participation when they tried to involve exwives in child-related decisions. Only 2 of the 6 fathers whose wives did not accept them reported regular decision-making interactions. The rest reported that a past history of arguments and uncooperative coparenting interactions, coupled with perceptions of exwives badmouthing them to the children, eventually led to fewer interactions and less joint decision-making (e.g., "I parent on my own [because] it's so much easier than having to parent with her." -Ben).

Other coparenting behaviors reported by fathers who did not feel accepted included restrictive maternal gatekeeping (e.g., withholding access to children, 
withholding information about the children, and mothers making unilateral decisions) and undermining behaviors (e.g., attempts to sabotage father's vacation by presenting noncrisis child-related issues as a crisis needing immediate response). Undermining behaviors frequently included badmouthing fathers to children, usually based around the father's sexuality (e.g., "She bashed me to the kids...the gay thing was played pretty hard." -Mark). Badmouthing also occurred when ex-wives attempted to instruct children religiously:

[My son] just breaks down crying, out of nowhere, and says “I don't want to go to heaven, Dad." And I'm like "Why are you saying this? Of course you want to go to heaven." "No, cause you're not gonna be there." And by this time my daughter chimes in and says "Well, Mom says that you're not going to heaven, that you're gonna be with Satan." It hurt to hear them say that- they're not equipped to deal with it. I was pissed at my ex-wife, because even if she felt this it's not what you tell a 7- and 9-year old... this is the kind of stuff she emotionally tortures them with. -Tom

Coparenting Satisfaction. To frame discussions of coparenting satisfaction, during interviews, fathers were asked to rate on a scale from 1-10 (with 10 being the highest score; see Appendix D) how satisfied they were with the post-divorce coparenting relationship. These ratings were a minor part of the overall interviews, yet they provided a reliability check. The fathers who felt accepted had an average satisfaction rating of 8.90; those who felt unaccepted averaged a 5.

Almost all of the fathers who perceived acceptance said that their satisfaction with coparenting quality either had remained the same over time $(n=4)$ or had improved $(n=4)$, 
generally after a transitional period of about a year. The one father in this group whose satisfaction with coparenting quality had slightly dissipated over time said this was due to frustrations connected to moving out of state, which made coparenting decisions less practical. He did not express resentment towards his ex-wife or report restrictive maternal gatekeeping, and perceived his wife to excitedly support the possibility of him moving back to be closer to his son.

The fathers who felt neither understood nor accepted as gay men reported that their ex-wives consistently communicated homonegativity, which compromised both coparenting quality and their satisfaction with it (e.g., "The religious aspect of this [referencing ex-wife's religiously-based homonegativity] can be very, very challenging... it's part of everything, it's like it is weaved into every piece of our parenting." -Tom). The fathers' stories regarding their coparenting relationships led to the identification of conclusion two: If fathers perceive that their ex-wives believe their gayness is a choice, then coparenting quality is negatively affected. For most of these fathers, satisfaction with coparenting did not improve over time. It either remained the same $(n=3)$ or declined $(n=2)$. Two fathers, who had been divorced longer than the others, became more satisfied as their children became older and more independent, which reduced their need to interact with their ex-wives. William, who reflected that getting full custody of his children had increased his satisfaction with coparenting because it decreased his interactions with his ex-wife, was still unsatisfied because she continued to badmouth him (e.g., "She's passive aggressive, but I stay aware of what she says and does behind the scenes...she's a Christian fundamentalist and my orientation is a big issue for her, and that is communicated to our children."). 


\section{Processes of Acceptance}

Most fathers, especially those who had been divorced longer, described their coparenting relationships as complex and evolving (even if their overall satisfaction had changed very little) and pointed to social environments that they believed affected their ex-wives' coparenting. Fathers who felt accepted generally reported that their ex-wives held religious beliefs towards sexuality with little religiously-based homonegative influences. For some, acceptance increased when their ex-wives began interacting more with other gay and lesbian individuals or developed a greater awareness of LGBTQ issues and communities.

A minority $(n=2)$ of unaccepted fathers whose ex-wives had been less entrenched in conservative religious communities, said that their ex-wives had decreased their homonegative beliefs or that their stances had become less harsh (e.g., one ex-wife "lightened up" in response to what the father believes to be a general re-evaluation of life following her mother's battle with a terminal illness; another's homonegativity decreased after her remarriage ended).

Fathers felt less accepted when ex-wives increased their involvement with homonegative family members, friends, and churches, and whose religiously-based homonegative views were deeply engrained and stable over time. For example, 10 years after Tom came out to his ex-wife, and 5 years after they divorced, he reported that his ex-wife continued to send him religious messages (e.g., song quotes, inspirational messages on "God's plan") in an attempt to be helpful to him in what she believed his spiritual path should be - returning to suppressing his gay identity. Another father, Matt, reported that his children told him their mother continued to hold a church prayer group 
in her home that prayed for him to change. The more deeply fathers believed their exwives felt homosexuality was wrong, the more they felt coparenting was negatively impacted

It's difficult. She still believes it's a choice, and she tells the kids "Life is about choices, and that's a choice your father made." I think she became quite a martyr, but there's a point in time when you have to just get over it and move on, and even now [after remarriage] she hasn't really moved on...it's still difficult. -Matt At the same time, most fathers who felt unaccepted also believed that their exwives used homonegativity as a tool to make sense of their marriages ending and to support ongoing resentment towards their ex-husbands (e.g., "that belief system, it's a way that allows her to get back at me" -Tom). John felt that the religiously-based rhetoric and homonegative language used by his ex-wife immediately after the divorce did not reflect strongly held religious convictions on gayness, but instead provided a rationale for her expressions of anger.

She pulled out all this religious fundamentalism crap that I never knew ran so deep. She claimed that I had defied God's will and that I was a butt-fucking fag, and would say that in front of the children all the time. I think she was pulling out any weapon she could find to hurt me; she was grasping at straws. Christianity was just a tool for her. - John.

Eventually, she was able to accept John's sexuality, process their divorce, and build a cooperative coparenting relationship. Within 3-4 years of their divorce their relationship had evolved to be fairly close and positive, and they were able to coordinate family events together and cooperate on child-related decisions. His ex-wife even offered 
for John and his partner to stay at her house anytime they were in town. John's story is largely different, however, from the other fathers who felt low acceptance, because his ex-wife was eventually able to fully accept his gayness and build a cooperative postdivorce coparenting relationship. Her use of homonegativity lessened over time, and the two were able to reconcile his coming out and their marriage ending.

She [originally] thought gay men are incapable of understanding what men need to be in their children's lives, but often her accusations didn't ring true. She found out there were lots of fathers who are gay, and it doesn't make you a good or bad parent. And it's untenable for her to hate if she's truly a Christian, which I pointed out to her... There were tons of little conversations [where she conveyed acceptance]. I said "I know you perpetrated this theory that somehow I planned all this, but it was a complete series of well-intentioned decisions leading to hell. Gay wasn't on the agenda" She said "Why didn't you take responsibility for it?" And I said "What do you think coming out is?" I think that's where she reconciled it. She couldn't straighten me out, and she didn't need to. -John John was the only father who initially reported strong hostility and unacceptance but later felt fully accepted and satisfied with their cooperative coparenting relationship. The other unaccepted fathers continued to think their ex-wives believed they were making a choice, which contributed to acrimony and low coparenting satisfaction. Religiously-based homonegativity appeared to be the driving force behind fathers feeling unaccepted, which conclusion three is drawn from: If fathers believe their ex-wives' hold religiously-based homonegative views, then they are more likely to feel unaccepted as gay men by them. 
Fathers' processes of acceptance. It was not just ex-wives who had trouble dealing with these men's gay identity. The fathers described their own process of adapting to accepting that they were gay and the need to live openly. These processes unfolded over many years. Although it was not my intention to examine religiously-based homonegativity, it emerged as a consistent influence on the fathers' lives. The fathers' process of accepting being gay involved examining the congruency of their gay identities and their religious beliefs.

Their ideas on religion changed after coming out and the role of religion in their lives became more diverse. Most fathers maintained their basic convictions and spirituality, yet their approach to religion changed. Those whose religious backgrounds were the most conservative adapted their religious views the most. They described developing belief systems that still allowed them to find meaning and support through faith while shedding the negative, stigmatizing aspects of religiously-based homonegativity. The religious beliefs and practices of the fathers at the time of the interviews were on a continuum, although their experiences clustered into three general groups.

Four of the men seldom attended church, yet felt religious beliefs were central to their lives. They felt unwelcome at some churches and were either unable to find gay accepting churches or were not ready to begin searching (e.g., "The pastor told me he doesn't agree with my "lifestyle choice", and I feel like I'm intruding every time I visit, so I don't. But I still hold to many Christian teachings, and someday I'll find a fellowship to be with."-Chris). Six men also felt religious beliefs were central to their lives and regularly attended church and held leadership roles. They reported finding acceptance as 
gay men from their congregations and church leaders (e.g., "It's always been such a big part of my life, and I felt so much relief [after talking with the priest] when I realized that I wasn't going to have to give up what I'd followed all my life.”-Joe).

The remaining six fathers' religious affiliation ranged from atheist to agnostic to vaguely spiritual. They did not attend church and did not feel religion was central to their lives. Three of these fathers reported religion had never played a major role in their lives; the other three had made active decisions to leave organized religion because of negative experiences (“I feel burned by the whole church experience”. -Ben). They also reexamined their participation in a belief system that had been a large force behind their suppression of a gay identity ("It personally seemed to me that the denial of my sexuality was in some ways bound with telling myself stories about religion and things I didn't really believe.... a theme of self-delusion, I suppose." -Bill). No matter where the fathers fell along the continuum of religiosity, religiously-based stigma from family, community, and organized religion had shaped their experiences as gay men.

Fathers' acceptance and expression of their gay identities required dealing with stigma from within as well as from heterosexual and gay communities. Fathers complained that others assumed gay stereotypes about them such as they were attracted to all men (e.g., male coworker uncomfortable being in bathroom at same time) and were deviants (e.g., pedophiles; "having wild parties and engaging in "God knows what"” Truman). Fathers rejected gay stereotypes and questioning of their ability to be a father as well as references to their sexual identity as a lifestyle choice as they sought to live with authenticity. 
I look back on it now and I'm glad that it all happened, because it was a catalyst to really make me dig inside myself and really work towards who am I...as a gay man and gay dad. -Nipper

Their social lives did not change radically after coming out, in that most weekends were centered around activities with children (for those with younger children), and most of their social contacts were with both gay and heterosexual families whose children were similar ages. Those involved with church socialized with people from church. Most importantly, they did not believe that their commitment as fathers was affected by being gay (e.g., "Being gay doesn't change my being a parent...my kids are always going to be first." -Mark).

About half of the fathers felt coming out as gay had positively impacted their parenting by causing them to be more open emotionally (e.g., "In some ways it's made it easier to talk about emotional and personal issues because that's sort of all been out in the open." -Bill) or able to personally represent their values to children (e.g., "I just think I'm a better father because I'm modeling that I'm happy, and I'm not hiding anything, but being true... and hopefully they someday will be true to whoever they are." -Matt). Although those from more conservative backgrounds who had more recently come out and divorced appeared to hold more internalized stigma (e.g., "I've finally came to the conclusion that I'm not broken and don't need to be fixed, but some days still struggle with being gay." -Tom), the majority had largely reconciled internalized homonegativity, and none felt their identities as both gay men and fathers were, mutually exclusive or incompatible.

These men viewed their sexuality as only one aspect of their identity and that 
sexuality by itself did not determine one's parenting ability (e.g., "To the outside world it means a lot, but being gay has so little to do with the relationship between me and my kids." - John). Consider how RR, who was one of the most satisfied with his coparenting relationship, talked about how his gay identity was related to his fatherhood and coparenting roles:

I don't care if you're gay or straight, you have a responsibility to your children and they have to come first in your life. For me the fact that I was gay did not have an effect on my parenting or my responsibility thereof. Luckily, neither my children or my ex-wife viewed my sexuality as being an impediment to me filling that role... I'm very satisfied with [the coparenting relationship], it's extremely positive. [Do you think her being open minded about sexuality influenced your relationship?] Absolutely, without question. -RR

On the other hand, Truman, who was one of the least satisfied with his coparenting relationship, felt his gay identity was viewed as incompatible with fathering and coparenting. Although saddened over the loss of his relationship with his children and angered by how his ex-wife had negatively framed his sexuality to them, he ultimately remained hopeful to build a relationship with them independent of his exwife's influence:

My fatherhood's been stripped, and I've had to fight to get, just get contact, let alone be a parent. It's almost like the two worlds are independent of each other. My children are in this one, and I'm in this, this one, and there's no intermingling with any of it. I wanted to do the right thing and be honest, but I didn't know that I was gonna sacrifice knowing my children or the relationship that I had with my 
ex. She's bitter [because of] her belief that she's right and I'm wrong, and in her opinion that she is the only parent that matters. It caught me by surprise, but what I've come to is that I've gotta continue pursuing things that interest me, challenge me, and keep me interesting as a person... Because if I do get a chance to be around my children, then I've got to work to be a person that's worth being around. -Truman

\section{Conclusion}

The coming out process for the men in this study was slow and painful, and some still experienced guilt and struggle with being gay. However, they worked for years to overcome stigma and to come out, and living openly as a gay man was important to them. Equally important to them were their roles as fathers. These men had intentionally become fathers and perceived themselves as more involved than the average father (particularly when they were married or their children were younger). Overall, they viewed their father and gay identities as compatible rather than mutually exclusive, even if others do not.

The development of cooperative post-divorce coparenting relationships appeared to be compromised when fathers perceived expressed homonegativity from their exwives, which led them to feel rejected as both coparents and gay men. Although all the fathers initially perceived some anger from their ex-wives, those who felt their ex-wives held to religiously-influenced views of gayness as an immoral choice believed this anger persisted for years after they divorced and continued to negatively affect coparenting quality. The ex-wives' anger and uncooperative coparenting, in their view, was largely 
due to ex-wives' inability to move on from the divorce and was reinforced by families, community mores, and, most often, organized religious groups. 


\section{Chapter 4: Discussion}

Despite the anti-homosexual and gay marriage stances of many religious institutions, there are increasing signs of a lessening or reversing of such stances among religious sects (Oswald \& Holman, 2013), and social and legal opinions in the U.S. regarding homosexuality are rapidly changing (PEW, 2013). These changes have led younger gay men to come out earlier and be less likely to marry women than in the past (Patterson \& Riskind, 2010). These changes are also likely contributing to more older gay men in heterosexual marriages coming out. In spite of an improved social climate, however, LGBTQ persons continue to be stigmatized, so it is likely that men who want to be fathers and have a family will still enter heterosexual marriages (Higgins, 2004; Lynch 2004). In this study, I sought to find out what happens to the coparenting process when these men who are married to women are no longer able to mask their gay identity and divorce.

Although the men were at least partially aware of their gay tendencies when they married, they maintain that they were in love with their ex-wives at the time. This could be creative reconstruction to feel less guilt, but a few fathers said that they still love their ex-wives at least as friends or family members, and establishing cooperative coparenting relationships are easier for them. These fathers' post-divorce coparenting relationships more closely resemble Ahrons' (1994) “perfect pals” arrangement- good communication, respect of each other's parenting.

Although research on heterosexual parents finds that better quality post-divorce coparenting relationships ensue when parents believe the dynamics of their marriages were more positive (Pruett, Arthur, \& Ebling, 2007), some fathers ( $\mathrm{n}=3$ ) with cooperative 
coparenting relationships believed that divorce was inevitable, even if they were not gay. Post-divorce coparenting quality, therefore, is more than an extension of the marital coparenting quality. In the perception of these gay fathers, the key factor to cooperative coparenting is their ex-wives' acceptance of their gay identity, their awareness that these men are not choosing to be gay, and their respect for these men as fathers. Fathers who do not describe cooperative coparenting believe their ex-wives' homonegative views continue to be shaped by religious influences.

In examining divorced gay fathers' coparenting experiences, it is necessary to understand the context for why they suppressed being gay as well as why they married women. Conservative social environments led to shame during the men's early inclinations of possibly being gay. An overlay of religious doctrine additionally fueled feelings of gayness as immoral or wrong. Previous work connecting homonegative environments to internalized stigma, suppression, and denial of homosexuality is well documented (e.g., Dunne, 2001; Herek, Gillis, \& Cogan, 2009; Higgins, 2004, Pachankis \& Goldfried, 2004). The fathers' past experiences of suppressing a gay identity due to religiously-based homonegativity, and ultimately rejecting these ideologies by coming out, contextualize their current identities and how they coparent, especially if their exwives still communicate such ideologies. These findings on divorced gay fathers' coparenting experiences speak to the importance of ex-wives' acceptance of fathers' homosexuality (the core theoretical concept of this study) and the resulting three main conclusions presented. Although the focus of this study is novel, these findings can be speculated on and connected to what we know about gay fathers and post-divorce coparenting in general. 
Ex-wives' anger and uncooperativeness may be rooted in how they process their husbands' gayness and their divorce. Although virtually all divorcing parents go through a process of navigating anger, hurt, or sadness over their divorce as they transition into their post-divorce coparenting relationships (e.g., Ahrons, 1981; Bonach, 2007), the exwives of gay men additionally encounter a process related to their husbands' newlydisclosed sexuality. Buxton's $(1994,2009)$ work on how the wives of gay men cope posits that they often proceed through a sequence of emotions (e.g., hurt, anger, fear, grief). She notes, however, that if these emotions are not constructively handled, the coping process could cease or reverse. If this happens, religiously-based homonegative beliefs may exacerbate feelings of anger and hurt and leave ex-wives stuck in anger.

Aside from earlier work suggesting that religiously-based homonegativity influences ex-wives' coping processes and their messages to children about their fathers (e.g., Buxton, 2009; Gardner, 2004; Gochros, 1989), the influence of religious beliefs on coparenting has received little direct examination. We do know that for ex-wives and other family members, the influence of these beliefs on acceptance largely depends on the extent to which social contexts reinforce or dispel homonegativity (Buxton, 2009; Lease \& Shulman, 2003). The more consistently homonegative an ex-wife's social influences are, the less accepted the father feels.

The fathers' reports of coparenting communication, behaviors, and their satisfaction with coparenting is heavily influenced by whether or not their ex-wives' accept them as gay men. When accepted, gay men give their ex-wives credit for adjusting and view them more favorably as coparents. Wives who are able to convey a level of understanding of their gay ex-husband's situation are also perceived as either setting 
aside or decreasing anger so that coparenting is not affected. Accompanying this is a reduction in blaming and an increase in forgiving. Conversely, fathers who feel rejected perseverate on their ex-wives' lack of acceptance and their dissatisfaction with the coparenting relationship. These fathers' descriptions of coparenting are similar to Ahron's (1994) "angry associates" or "fiery foes"; coparents who refuse to accept their ex-spouses as reliable parents and work to undermine their relationships with the children.

It is not unusual for divorcing parents to blame each other for divorce (e.g., Levite \& Cohen, 2012), even when sexual orientation is not an issue. Because the stories shared here are from the fathers' perspective, it is not surprising that they implicate their exwives as the main or sole contributor to creating a negative coparenting climate. Whether this is accurate or not, it is clear that lack of acceptance makes gay fathers angry with their ex-wives as coparents.

Fathers' coparenting. The fathers' reports surely contain some level of accuracy in how their ex-wives behave as coparents, however, it is important to take a step back from the fathers' stories and consider them more objectively. Whereas fathers who feel rejected believe their ex-wives are poor coparents, these fathers also express acrimony towards their ex-wives for that rejection. This acrimony may color their objectivity about the coparenting relationship and affect their own cooperation in the coparenting process.

An overarching reason that perceptions of unacceptance may matter to fathers is related to their identity work after coming out. These men all experienced an internal process of accepting themselves as gay and then integrating this with their identities as fathers. Research on gay fathers suggests this is no easy task, yet an essential one (e.g., 
Armesto, 2002; Benson et al., 2005). Classic models of the coming out process can be applied (e.g., Cass, 1979; Coleman, 1982) to these men's identity development. LGBTQ individuals must first overcome internal stigma around a homosexual identity, and then begin to integrate this gay identity with their other identities. The ultimate goal of coming out, then, is to "acquire an identity of 'homosexual' that is fully integrated within the individual's overall concept of self' (Cass, 1979, p. 220). For the most part, the fathers in this study are similar to those in Benson et al.'s (2005) study in that after years of identity work, they now feel pride in being gay and being a father.

As would be suggested by symbolic interaction theory, this identity work does not occur in a vacuum. Reactions from others play a role in the process. How critical the reaction of others is depends on their importance to the person coming out (Rust, 2003). The fathers in this study were intimately partnered with their ex-wives for much of their lives, and they will remain connected with them indefinitely through their children. Therefore, when these women consistently communicate that their gay identities are "less than" (e.g., an immoral choice, character defect, compromising to their abilities to father or coparent), a challenge is presented to their process of gay identity integration.

Symbolic interactionism (SI; Mead, 1934), would suggest that divorced parents' satisfaction with their coparenting relationships involves considering how the views of others, such as ex-spouses, family members, and court systems, fit with their own attitudes and expectations for post-divorce coparenting. Previous applications of this theory to post-divorce coparenting find that fathers' involvement and satisfaction with their post-divorce coparenting relationships are tied to how confident fathers feel in their fatherhood role as well as the level of support they perceive from ex-wives (Adamsons \& 
Pasley, 2006). Those who feel confident about their fathering abilities and believe that their ex-wives are similarly confident in them as fathers and who support them as equal coparenting partners, assess their coparenting relationships more positively. The coparenting satisfaction of the fathers in this study, then, involves their assessments of how ex-wives' attitudes toward them either acknowledge or disrupt their internalized identities as gay men and fathers.

Although applying SI to coparenting suggests that the attitudes of ex-spouses are generally the main influence in how coparenting relationships are evaluated, the views of others, such as those communicated by social institutions, are relevant as well. For example, fathers' views on their coparenting relationships also incorporate their experiences in court. All but one of those who feel unaccepted believes their ex-wives tried to use their gayness against them when negotiating child custody. Half of them believe that attorneys and judges also thought their gayness compromised their fathering abilities. Even if the ex-wives were ultimately unsuccessful in their attempts to refute their ability as good fathers, the fathers still cite their ex-wives' expressions of homonegativity as part of the reason they view them as unreasonable and uncooperative coparents. All in all, any communications of not accepting them as both gay men and good fathers seems to contribute to fathers' frustration with their ex-wives as coparents.

Ex-wives' coparenting. The fathers' stories present a clear relationship between their feelings of acceptance as gay men and their beliefs about the quality of the coparenting relationship. Assuming that fathers' reports contain some level of accuracy concerning their ex-wives behavior as coparents, we can also speculate about how exwives' rejection may affect coparenting. We know from research on divorced 
heterosexual couples that parents' feelings about each other are linked to coparenting quality. Divorced parents who attribute most of the blame for the divorce to their exspouses are less likely to coparent cooperatively. They may feel justified in these behaviors due to their perceptions of being wronged by the other parent (Bonach \& Sales, 2002; Bonach 2005). If these feelings of blame, anger, and resentment diminish over time, forgiveness of perceived wrongdoings may begin to occur. This, in turn, can allow parents to move on with their lives, decrease their hostility, and develop a deeper understanding of their ex-partner (Gordon \& Baucum, 1998). The role of forgiveness after divorce is receiving increased attention (e.g., Bonach, 2007, 2009; Bonach \& Sales, 2002; Rohde-Brown \& Rudestam, 2011), and how ex-spouses' cognitively engage in forgiveness and replace negative emotions with positive ones is predictive of improved coparenting quality (Bonach, 2005, 2007). The more blame a parent harbors towards their ex-spouse, the less likely they are to forgive and engage in cooperative coparenting.

According to the men in this study, all of the ex-wives were originally upset about the divorce and, at least initially, communicated varying levels of blame towards fathers because they came out as gay. Those who now understand their husbands are not choosing to be gay or act maliciously to destroy their families, no longer hold on to their anger or blame in ways that fathers feel affect the coparenting relationship. Ex-wives who view gayness as wrong and a choice, however, continue to blame fathers and picture themselves as victims of father's whims. These ex-wives often engage in retribution by restrictively gatekeeping (e.g., including attempts to restrict time with children through custody orders) or not attempting to meaningfully engage in coparenting with them, and are seen by the fathers as undermining them to children. 
Negative coparenting may also be the result of symbolic meanings ex-wives apply to their marriages ending and how oppositionally they view fathers. Hopper (2001) suggests that most Americans view marriage as sacred and permanent. Those who more deeply hold this view also feel a stronger need to interpret the end of their own marriages in ways that preserve the sacredness of marriage while lessening their role in the destruction of it. Conflict is more intense and continuous when there is less congruence between divorcing spouses regarding why they believe their marriages ended, especially when the divorce is seen by either party as a result of (1) being a broken marriage that never was true love or companionship, or (2) the intentional deceitfulness of one partner (Hopper, 2001). It is perhaps not surprising, then, that ex-wives whom fathers described as less cooperative coparents hold more conservative religious views (e.g., homonegative, marriage as sacred), and their divorce stories, according to the fathers, involve seeing fathers as maliciously choosing to be gay and wronging them. Social messages also affect how mothers coparent (Ganong, Coleman, Markham, \& Rothrauff, 2011), and ex-wives who consistently receive homonegative messages from family and others regarding their ex-husbands likely value them less as coparents.

\section{Limitations and Research Implications}

Although this study provides new insight into gay fathers' perceptions of postdivorce coparenting relationships, a major limitation is that ex-wives' perceptions were not included. The perspectives of ex-wives whose husbands came out as gay has been studied independently (e.g., Buxton, 2009; Gochros, 1989), but these researchers did not examine how these perspectives affect post-divorce coparenting. Future research should examine couple data to determine how factors such as attitudes towards the other parent 
and beliefs about coparenting can affect the dynamics of these relationships as well as those of heterosexual post-divorce coparents (e.g., Ganong et al., 2011).

Although a strength of this study involved using in-depth interviews to probe for rich data (Creswell, 2007), a limitation is that the data only reflect fathers' current perceptions on a relationship that is often complex and changing (Adamsons \& Pasley, 2006; King \& Heard, 1999; Maccoby \& Mnookin, 1992). The sample represented a fairly broad range of time since divorce (i.e., from less than two years to over 28), and fathers' recollections of how the coparenting relationship may or may not have changed may reflect different sentiments than they would have reported earlier, or will report in the future. Future research that follows divorced gay fathers over several years could provide a better understanding of coparenting relationship processes, including changes over time, as well as help explain why conflictual and uncooperative coparenting may persist for years after divorce for some couples (i.e., roughly 10-25\%; Amato, Kane, \& James, 2011).

Finally, the fathers interviewed were somewhat homogeneous in terms of race, age, socioeconomic status, religious background, and communities of origin. Although homogeneity is not surprising given the role conservative social and religious values often play in rural communities (e.g., Benson et al., 2005), future work should involve more diverse samples, particularly in terms of race and ethnicity. This study finds that gay fathers' post-divorce coparenting processes are related to expectations and support for their identities as fathers, coparents, and gay men. These concepts are socially constructed, and it is likely that the men's demographic similarities affect their experiences in these roles (e.g., Catlett \& McKenry, 2004; Rust, 2003; Lamb, 2010; 
Troilo \& Coleman, 2012).

\section{Conclusion}

An important task for parents after divorce is to process anger and redefine their relationship to one another as coparents (Ahrons, 1981). Although gay men face unique challenges, the results of this study underscore the need to consider the attitudes and beliefs of ex-spouses on coparenting relationships across family types (e.g., heterosexual, gay, lesbian, and mixed sexuality couples after divorce). Coparenting following the divorce of gay men and their wives may be even more complex than that divorced heterosexual couples, yet most fathers $(n=9)$ in this study identify their coparenting relationships as cooperative. The reasons for this are largely the same as those for many heterosexual fathers. Divorced heterosexual fathers appear to have better coparental interactions with their children's mothers after divorce when: (a) mothers support and encourage father's involvement in coparenting (Cohen \& Finzi-Dottan, 2005); (b) fathers are more satisfied with their parenting and parenting role (Madden-Derdich \& Leonard, 2002; Olmstead, Futris, \& Pasley, 2009); and (c) when fathers are able to establish salient parenting identities (DeGarmo, 2010). Ex-wives' support or undermining of fathers' postdivorce coparenting identities is an important factor for coparenting quality.

We know from previous research that establishing positive coparenting relationships are important for children's wellbeing in post-divorce families (e.g., Amato, Kane, \& James, 2011; McBroom, 2011; McHale et al., 2002), and accordingly a range of coparenting intervention efforts exist. Coparenting education programs offered to divorcing parents should continue to make parents aware of the negative effects on children of uncooperative coparenting, yet be expanded to address how important 
parents' assessments of their former partners as coparents is to the quality of the coparenting relationship. Religiously-based divorce support groups in particular can help foster cooperative coparenting, in as much as religious belief systems promoting forgiveness may help parents process their divorces and redefine their coparental relationships in positive ways (Reilly, 2014). However, religious values of forgiveness may be negated for those involved in divorces where one parent comes out and the other clings to strong religiously-based homonegativity.

Navigating conflicting religious ideologies when one parent is gay may present a unique challenge. Although religious disagreements for couples with different denominational backgrounds or when one spouse is significantly more religious than the other, have been found to contribute to lower marital quality and a higher likelihood of divorce (e.g., Schramm \& Lester, in press), the influence of religious beliefs on postdivorce coparenting are receiving little examination. The effect of religiosity on family relationships is complex, and examinations of how different levels and types of religiosity may affect families have been cited as a need (e.g., Dollahite, Marks, \& Goodman, 2004). For many divorced gay fathers, religiously-based homonegativity exerts a fairly consistent influence on their lives.

The results of this study are not meant to polarize or to negate the importance of religious experience. Most of the fathers in this study identify religious beliefs as important to their lives. Spirituality and religious beliefs can provide meaning to the struggles LGBTQ individuals face (Tan, 2005), even as they work to overcome religiously-based homonegativity and the challenges of divorce and coparenting. The slow cultural shift from religiously-based homonegativity offers hope for those who 
come out in heterosexual marriages to experience higher quality post-divorce coparenting relationships. More importantly, this trend reinforces a generational shift away from viewing homosexuality as an unacceptable pathway to parenthood and family. An important finding from this study is the importance for families and the organizations, policymakers, and religious groups that shape their experiences to continue the trajectory towards acceptance and fully recognized equality for LGBTQ individuals and families. 


\section{References}

Adamsons, K. (2010). Using identity theory to develop a mid-range model of parental gatekeeping and parenting behavior. Journal of Family Theory \& Review, 2, 137 148.

Adamsons, K., \& Pasley, K. (2006). Coparenting following divorce and relationship dissolution. In M. A. Fine \& J. H. Harvey (Eds.), Handbook of divorce and relationship dissolution (pp. 241-261). Mahwah, NJ: Lawrence Erlbaum Associates.

Ahrons, C. (1994). The Good Divorce: Keeping your family together when your marriage comes apart. New York, NY: HarperCollins.

Ahrons, C. R., \& Rodgers, R. H. (1987). Divorced families: A multidisciplinary developmental view. New York, NY: Norton.

Amato, P. R. (2010). Research on divorce: Continuing trends and new developments. Journal of Marriage and Family, 72, 650-666.

Amato, P. R., \& Gilbreth, J. G. (1999). Nonresident fathers and children's well-being: A meta-analysis. Journal of Marriage and Family, 61, 557-573.

Amato, P. R., Kane, J. B., \& James, S. (2011). A reconsideration of the good divorce. Family Relations, 60, 511-524.

Armesto, J. C. (2002). Developmental and contextual factors that influence gay fathers' parental competence: A review of the literature. Psychology of Men \& Masculinity, 3, 67-78.

Barret, R. L., \& Robinson, B. E. (2000). Gay fathers: Encouraging the hearts of gay dads and their families. San Francisco: Jossey-Bass.

Barrett, H., \& Tasker, F. (2001). Growing up with a gay parent: Views of 101 gay fathers on their sons' and daughters' experiences. Educational and Child Psychology, 18, 62-77.

Benson, A. L., Silverstein, L. B., \& Auerbach, C. F. (2005). From the margins to the center: Gay fathers reconstruct the fathering role. Journal of GLBT Family Studies, 1(3), 1-29.

Biblarz, T. J., \& Savci, E. (2010). Lesbian, gay, bisexual, and transgender families. Journal of Marriage and Family, 72, 480-497.

Bigner, J. J., \& Jacobsen, R. B. (1989a). The value of children for gay versus nongay fathers. Journal of Homosexuality, 18, 163-172. 
Bigner, J. J., \& Jacobsen, R. B. (1989b). Parenting behaviors of homosexual and heterosexual fathers. In F. W. Bozett (Ed.), Homosexuality and the family (pp. 173-186). New York: Harrington Park.

Bonach, K. (2007). Forgiveness intervention model: Application to coparenting postdivorce. Journal of Divorce \& Remarriage, 48, 105-123.

Bonach, K. (2005). Factors contributing to quality coparenting: Implications for family policy. Journal of Divorce \& Remarriage, 43, 79-104.

Bonach, K., \& Sales, E. (2002). Forgiveness as a mediator between post divorce cognitive processes and coparenting quality. Journal of Divorce \& Remarriage, $38,17-38$.

Bozett, F. W. (1987). Gay and lesbian parents. New York: Praeger.

Buxton, A. P. (2009). Foreword II. In M. Ford (Ed.) Playing it straight: Gay men and heterosexual marriage (pp. 15-22). Bloomington, IN: Xlibris.

Buxton, A. P. (2001). Writing our own script: How bisexual men and their heterosexual wives maintain their marriages after disclosure. Journal of Bisexuality, 1, 155189

Buxton, A. P. (1994). The other side of the closet: The coming-out crisis for straight spouses and families. New York: Wiley.

Catlett, B. S., \& McKenry, P. C. (2004). Class-based masculinities: Divorce, fatherhood, and the hegemonic ideal. Fathering, 2, 165-190.

Carlson, M. J. (2006). Family structure, father involvement, and adolescent behavioral outcomes. Journal of Marriage and Family, 68, 137 - 154.

Carlson, M. J., McLanahan, S. S., Brooks-Gunn, J. (2008). Co-parenting and nonresident fathers' involvement with young children after a nonmarital birth. Demography, $45,461-487$.

Cass, V. (1979). Homosexual identity formation: A theoretical model. Journal of Homosexuality, 4, 219-235.

Cohen, O., \& Finzi-Dottan, R. (2005). Parent child relationships during the divorce process, from attachment theory and intergenerational perspectives.

Contemporarily Family Therapy, 27, 81-99.

Coleman, E. (1982). Developmental stages of the coming out process. Journal of Homosexuality, 7, 31-43. 
Coltrane, S. (2004). Fathering: Paradoxes, contradictions, and dilemmas. In M. Coleman, \& L. Ganong (Eds.), Handbook of contemporary families: Considering the past, contemplating the future (pp. 224-243). Thousand Oaks, CA: Sage.

Corbin, J., \& Strauss, A. (2008). Basics of qualitative research (3rd ed.). Los Angeles: Sage.

Creswell, J. W. (2007). Qualitative inquiry and research design: Choosing among five approaches. Thousand Oaks, CA: Sage.

DeGarmo, D. S. (2010). A time varying evaluation of identity theory and father involvement for full custody, shared custody, and no custody divorced fathers. Fathering, 8, 181-202.

Dollahite, D. C., Marks, L. D., \& Goodman, M. (2004). Families and religious beliefs, practices, and communities: Linkages in a diverse and dynamic cultural context. In M. J. Coleman \& L. H. Ganong (Eds.), The handbook of contemporary families: Considering the past, contemplating the future (pp. 411-431). Thousand Oaks, CA: Sage.

Dunne, G. A. (2000). The different dimensions of gay fatherhood: Exploding the myths. London School of Economics and Political Science Gender Institute Discussion Paper Series, 8. Retrieved from http://www.lse.ac.uk/genderinstitute/pdf/gayfatherhood.pdf

Dunne, G. A. (2001). The lady vanishes? Reflections on the experiences of married and divorced non-heterosexual fathers. Sociological Research Online, 6(3). Retrieved from http://www.socresonline.org.uk/6/3/dunne.html

Finfgeld-Connett, D. (2014). Metasynthesis findings: Potential versus reality. Qualitative Health Research, ,1-11.

Finzi-Dottan, R., \& Cohen, O. (2014). Predictors of parental communication and cooperation among divorcing spouses. Journal of Child and Family Studies, 23, $39-51$.

Ganong, L., Coleman, M., Markham, M., \& Rothrauff, T. (2011) Predicting postdivorce coparental communication. Journal of Divorce \& Remarriage, 52, 1-18.

Garner, A. (2004). Families like mine: Children of gay parents tell it like it is. New York: HarperCollins Publishers.

Gates, G. J. (2011). Family formation and raising children among same-sex couples. NCFR Family Focus on ..., 51, 1-4.

Galvin, K. M. \& Patrick, D. G. (2009). Gay male partners achieving joint parenthood: Communication issues and challenges. NCFR Family Focus on ..., 41, 18-19. 
Gochros, J. S. (1989). When husbands come out of the closet. Binghamton, NY: Harrington Park Press.

Golombok, S., \& Tasker, F. Gay fathers. In M. E. Lamb (Ed.), The role of the father in child development (5th ed., pp. 319-340). New York, NY: Wiley.

Gordon, K. C., \& Baucom, D. H. (1998). Understanding betrayals in marriage: A synthesized model of forgiveness. Family Process, 37, 425-449.

Harper, S. E. \& Fine, M. A. (2006). The effects of involved nonresidential fathers' distress, parenting behaviors, inter-parental conflict, and the quality of fatherchild relationships on children's well-being. Fathering, 4, 286-311.

Herek, G., Gillis, J., \& Cogan, J. (2009). Internalized stigma among sexual minority adults: Insights from a social psychological perspective. Journal of Counseling Psychology, 56(1), 32-43.

Higgins, D. J. (2002). Gay men from heterosexual marriages: Attitudes, behaviors, childhood experiences, and reasons for marriage. Journal of Homosexuality, 42, $15-34$.

Higgins, D. J. (2004). Differences between previously married and never married 'gay' men: family background, childhood experiences and current attitudes. Journal of Homosexuality, 48, 19-41.

Hopper, J. (2001). The symbolic origins of conflict in divorce. Journal of Marriage and Family, 63(2), 430-445.

Kamp Dush, C. M., Kotila, L. E., \& Schoppe-Sullivan, S. J. (2011). Predictors of supportive coparenting after relationship dissolution among at-risk parents. Journal of Family Psychology, 25, 356-365.

Kelly, J. B. (2000). Children's adjustment in conflicted marriage and divorce: A decade review of research. Journal of the American Academy of Child and Adolescent Psychiatry, 39, 963-973.

Kelly, J.B. \& Emery, R.E. (2003). Children's Adjustment Following Divorce: Risk and Resilience Perspectives. Family Relations, 52, 352-362.

King, V., \& Sobolewski, J. M. (2006). Nonresident fathers' contributions to adolescent well-being. Journal of Marriage and Family, 68, 537-557.

Krivickas, K. M., \& Lofquist, D. (2011). Demographics of same-sex couple households with children (SEHSD Working Paper Number 2011-11). Retrieved from U.S. 
Census Bureau website: http://www.census.gov/hhes/samesex/files/KrivickasLofquist $\% 20$ PAA\%202011.pdf

Kruk, E. (2010). Parental and social institutional responsibilities to children's needs in the divorce transition: Fathers' perspectives. Journal of Men's Studies, 18(2), 159-178.

Lamb, M. E. (Ed.). (2010). The role of the father in child development (5th ed.). New York: John Wiley \& Sons.

Lease, S. H., \& Shulman, J. L. (2003). A preliminary study of the role of religion for family members of lesbian, gay, or bisexual individuals. Counseling and Values, 47, 195-209.

Leite, R.W., \& McKenry, P.C. (2002). Aspects of father status and postdivorce father involvement with children. Journal of Family Issues, 23, 601-623.

Levite, Z., \& Cohen, O. (2012). The tango of loving hate: Couple dynamics in high conflict divorce. Clinical Social Work Journal, 40, 46-55.

Lewin, E. (2009). Gay fatherhood: Narratives on family and citizenship in America. Chicago: University of Chicago Press.

Lynch, J. M. (2004). The identity transformation of biological parents in lesbian/gay stepfamilies. Journal of Homosexuality, 47(2), 91-107.

Lynch, J. M., \& Murray, K. (2000). For the love of the children: The coming out process for lesbian and gay parents and stepparents. Journal of Homosexuality, 39, 1-24.

Maccoby, E.E. \& Mnookin, R.H. (1992). Dividing the Child: Social and legal dilemmas of custody. Cambridge, MA: Harvard University Press.

Madden-Derdich, D. A., \& Leonard, S. A. (2002). Shared experiences, unique realities: Formerly married mothers' and fathers' perceptions of parenting and custody after divorce. Family Relations, 51, 37-45.

Margolin, G., Gordis, E. B., \& John, R. S. (2001). Coparenting: A link between marital conflict and parenting in two-parenting families. Journal of Family Psychology, $15,3-21$.

Markham, M. S., Ganong, L. H., \& Coleman, M. A. (2007). Coparental identity and mothers' cooperation in coparental relationships. Family Relations, 56, 369-377.

May, S. (2001). Child custody and visitation. Georgetown Journal of Gender and the Law, 2, 382-401. 
McBroom, L. A. (2011). Understanding postdivorce coparenting families: Integrative literature review. Journal of the American Academy of Nurse Practitioners, 23, $382-388$.

McHale, J., Khazan, I., Erera, P., Rotman, T., DeCourcey, W., \& McConnell, M. (2002). Coparenting in diverse family systems. In M. Bornstein (Ed.), Handbook of parenting volume 3: Being and becoming a parent (pp. 75-107). Mahwah, NJ: Lawrence Erlbaum Associates, Inc.

Mead, G. H. (1934). Mind, self, and society. Chicago, IL: University of Chicago Press.

Oswald, R. F., \& Holman, E. G. (2013). Place matters: LGB families in community context. In A. E. Goldberg \& K. R. Allen (Eds.), LGBT-Parent Families (pp. 193 208). New York: Springer.

Olmstead, S. B., Futris, T. G. \& Pasley, K. (2009). An exploration of married and divorced, nonresident men's perceptions and organization of their father role identity. Fathering, 7 (3), 249-268.

Pachankis, J. E., \& Goldfried, M. R. (2004). Clinical issues in working with lesbian, gay, and bisexual clients. Psychotherapy: Theory, Research, Practice, and Training, 41, 227-246.

Patterson, C. J., \& Riskind, R. G. (2010). To be a parent: Issues in family formation among gay and lesbian adults. Journal of GLBT Studies, 6, 326-340.

PEW Research Center. (2013). In gay marriage debate, both supporters and opponents see legal recognition as inevitable. Retrieved September 10, 2014 from http://www.people-press.org/2013/06/06/in-gay-marriage-debate-both-supportersand-opponents-see-legal-recognition-as-inevitable/

Perrin, E. C. (2002). Coparent of second parent adoption by same-sex parents. Pediatrics, $109,341-344$.

Pruett, M. K., Arthur, L. A., \& Ebling, R. (2007). The hand that rocks the cradle: Maternal gatekeeping after divorce. Pace Law Review, 27, 709-739.

Reilly, E. W. (2014). The use of forgiveness in high-conflict divorce : A study of a psycho-educational approach to increasing forgiveness and coparenting. (Doctoral Dissertation). Retrieved August 26, 2014 from http://place.asburyseminary.edu/ecommonsatsdissertations/597/

Richards, L., \& Morse, J. M. (2006). Readme First for a user's guide to qualitative methods. Thousand Oaks, CA: Sage. 
Rohde-Brown, J., \& Rudestam, K. (2011). The role of forgiveness in divorce adjustment and the impact of affect. Journal of Divorce and Remarriage, 52(2), 109-124.

Ross, M. W. (1983). The married homosexual man: A psychological study. London: Routledge \& Kegan Paul.

Rust, P. C. (2003). Finding a sexual identity and community: Therapeutic implications and cultural assumptions in scientific models of coming out. In L. D. Garnets \& D. C. Kimmel (Eds.), Psychological perspectives on lesbian, gay and bisexual experiences (2nd ed, pp. 227-269.) New York: Columbia University Press.

Sandler, I., Miles, J., Cookston, J. T., \& Braver, S. L. (2008). Effects of father and mother parenting on children's mental health in high- and low-conflict divorces. Family Court Review, 46, 282-296.

Schramm, D. G., \& Lester, A. M. (in press). Religious heterogamy. C. L. Shehan (Ed.). The Encyclopedia of Family Studies.

Sobolewski, J. M., \& King, V. (2005). The importance of the coparental relationship for nonresident fathers' ties to children. Journal of Marriage and Family, 67, 11961212.

Stryker, S. (1968). Identity salience and role performance: The relevance of symbolic interaction theory for family research. Journal of Marriage and Family, 30, 558564.

Tan, P. P. (2005). The importance of spirituality among gay and lesbian individuals. Journal of Homosexuality, 49(2), 135-144.

Tasker, F., \& Patterson, C. J. (2007). Research on gay and lesbian parenting: Retrospect and prospect. Journal of GLBT Family Studies, 3(2/3), 9-34.

Tornello, S., \& Patterson, C. J. (2010). Gay fathers' pathways to parenthood: Has there been a generational shift? Unpublished manuscript, Department of Psychology, University of Virginia.

Troilo, J., \& Coleman, M. (2012). Full-time, part-time full-time, and part-time fathers: Father identities following divorce. Family Relations, 61, 601-614.

U.S. Census Bureau. (2011). Table C3: Living arrangements of children under 18 Years and marital status of parents, by age, sex, race, and hispanic origin and selected characteristics of the child for all children: 2011. Retrieved September 20, 2012 from http://www.census.gov/hhes/families/data/cps2011.html

West, C., \& Zimmerman, D. H. (1987). Doing gender. Gender \& Society, 1,125-151. 
Whiteside, M. F., \& Becker, B. J. (2000). Parental factors and the young child's postdivorce adjustment: A meta-analysis with implications for parenting arrangements. Journal of Family Psychology, 14, 5-26. 
Table 1

Participant Characteristics

\begin{tabular}{|c|c|c|c|c|c|c|c|}
\hline Father & Age & $\begin{array}{l}\text { Current } \\
\text { area }\end{array}$ & $\begin{array}{c}\text { \# of } \\
\text { children }\end{array}$ & Custody & $\begin{array}{c}\text { Marriage } \\
\text { length } \\
\text { (yrs.) }\end{array}$ & $\begin{array}{c}\text { Years } \\
\text { since } \\
\text { divorce }\end{array}$ & Repartnered \\
\hline $\mathrm{RR}$ & 52 & $\mathrm{~S}$ & 2 & $50 / 50$ & 14 & 13 & $\mathrm{Y}$ \\
\hline Nipper & 54 & $\mathrm{U}$ & 2 & $50 / 50$ & 20 & 10.5 & $\mathrm{~N}$ \\
\hline Gentry & 53 & $\mathrm{~S}$ & 3 & Joint, MP & 16 & 15 & Y \\
\hline John & 51 & $\mathrm{U}$ & 3 & Joint, MP & 25 & 6 & $\mathrm{Y}$ \\
\hline Bill & 56 & $\mathrm{~S}$ & 3 & $50 / 50$ & 19 & 9 & Y \\
\hline Kent & 37 & $\mathrm{~S}$ & 1 & $50 / 50$ & 5 & 10 & Y \\
\hline Mike & 36 & $\mathrm{U}$ & 1 & Joint, MP & 6 & 11 & Y \\
\hline Joe & 43 & $\mathrm{U}$ & 2 & Joint, MP & 17 & 3.5 & $\mathrm{~N}$ \\
\hline Frank & 30 & $\mathrm{U}$ & 1 & Joint, MP & 1.5 & 6.75 & $\mathrm{Y}$ \\
\hline Mark & 42 & $\mathrm{R}$ & 3 & Joint, FP & 7 & 10.5 & Y \\
\hline Truman & 49 & $\mathrm{~S}$ & 4 & Joint, MP & 22 & 1.9 & $\mathrm{Y}$ \\
\hline Chris & 40 & $\mathrm{U}$ & 3 & Joint, FP & 13 & 5 & $\mathrm{~N}$ \\
\hline Tom & 43 & $\mathrm{~S}$ & 3 & $50 / 50$ & 21 & 3.5 & $\mathrm{Y}$ \\
\hline Ben & 49 & $\mathrm{U}$ & 2 & Joint, MP & 14 & 8 & $\mathrm{~N}$ \\
\hline William & 59 & $\mathrm{U}$ & 4 & Joint, FP & 12 & 28 & $\mathrm{~N}$ \\
\hline Matt & 42 & $\mathrm{R}$ & 3 & $50 / 50$ & 15 & 4 & $\mathrm{Y}$ \\
\hline
\end{tabular}




\section{Appendix A. Recruitment Flyer Text}

\section{Are you a divorced gay Dad?}

If so, we'd love to talk with you about your experience!

The University of Missouri Department of Human Development and Family Studies is doing a study on the coparenting experiences of gay men with children from a previous heterosexual marriage. Participation in the study would involve 1-2 roughly 90 minute interviews that may be done in person or over the phone. Interviews will ask fathers about how they manage coparenting with their ex-spouses, including any unique challenges gay fathers may encounter.

For more information, please contact Graham at gayfatherstudy@gmail.com 


\section{Appendix B. Initial Recruitment Email}

\section{Dear XXXX,}

I am a PhD student in the Department of Human Development and Family Studies at the University of Missouri, and I am working on a dissertation about the experiences of gay fathers who have children from a previous heterosexual marriage. I am writing you to ask if you would be willing to participate in my study. Involvement would involve 1-2 roughly 1 hour interviews that may be done in person or over the phone.

\section{Study Purpose}

The purpose of my study is to tell the story of how fathers manage coparenting with their ex-spouses, including any unique challenges gay fathers may encounter. My approach celebrates diversity in families and does not view gay father families as flawed families. I only wish to examine post-divorce coparenting processes from the standpoint of the fathers. Little is known about how gay fathers with children from pervious heterosexual marriages coparent after divorce, and the aim of this study is to generate information that will be helpful to divorced fathers (of any sexuality) and those who work with them (e.g., family counselors, family life educators).

\section{Confidentiality}

All information from the study will be kept strictly confidential and any information shared (e.g., in the dissertation or any resulting publications) will be done so anonymously. This study has been approved by the University of Missouri's Institutional Review Board (573-884-0663 or umcresearchcirb@missouri.edu), which ensures studies' methods are respectful of participants and involve high levels of confidentiality and anonymity. My dissertation is also under the direction of a committee of MU professors headed by Dr. Marilyn Coleman (573-882-4360 or colemanma@missouri.edu).

\section{Contact Info}

Please let me know if you have any questions (573-289-2307 or gemwvd@mail.mizzou.edu), and if it would be possible to let fathers in your group know of the study. Any assistance would be greatly appreciated.

Thanks for your consideration,

Graham McCaulley, MA

PhD Student, Department of Human Development and Family Studies University of Missouri

314 Gentry Hall

Columbia, MO 65211 


\section{Appendix C. Written Consent Form}

\section{Divorced Gay Fathers Study}

You are invited to participate in a study on gay fathers being conducted by Graham McCaulley, a doctoral student in the Department of Human Development and Family Studies at the University of Missouri under the supervision of Dr. Marilyn Coleman. The purpose of this research is to better understand the coparenting experiences of gay fathers after they end a heterosexual marriage. If you agree to participate, I will conduct an approximately 90 minute in-depth interview about your experiences. I may ask if you would like to complete a shorter follow-up interview as well. Participation in this project is completely voluntary, and there will be no negative consequences if you choose not to participate. You are free to stop at any time or skip any questions that are asked. There are no penalties for stopping.

The benefit of participation is that you can help contribute to knowledge about gay fathers who have divorced. There is also a chance you will enjoy sharing your opinions and experiences.

The study is assumed to have little risk to participants, however, the research team does recognize the possibility that participants could encounter stigma (e.g., at work, in community) if they were identified as a gay man. Therefore, all contact with participants and data collected on participants will be kept confidential and any findings reported will be done in a manner that will protect your anonymity. It is also possible that participation may cause you some discomfort due to the topics raised in the interview. However, these risks are no greater than discussing sensitive issues with friends and family in an everyday setting. Specifically, you will be asked questions about coparenting, which may also involve questions about your previous marital relationship(s), the process of divorce, your current relationship with your ex-spouse(s), your relationship with your children, and your current romantic relationship (if applicable). If you experience any problems as a result of participating in the study, you may stop the interview at any time and ask the interviewer for a list of supportive services. If you would like to talk to a professional, staff at Behavioral Health Response (800-811-4760), or the Mid-Missouri Crisis Line (888-761-4357) are available to talk with you at any time of the day or night.

All information that is obtained during the study will be kept strictly confidential. I will record the interview with a digital recorder and later transcribe the interview for our records. Your name will not be directly connected to your responses. Instead, we will assign you a unique identification number that will be used on all documents associated with your interview. A list of names and corresponding ID numbers will only be available to Graham McCaulley and will be stored on a password-protected computer at the University of Missouri, as will other files for the study. After the study is completed we will publish a report of our research, but all information in the report will be anonymously reported.

If you have any questions about this study, please feel free to contact Graham McCaulley at 573-882-4035 or gemwvd@mail.missouri.edu or Dr. Marilyn Coleman at 573-882- 
4360 or colemanma@missouri.edu. You may also contact the MU Campus Institutional Review Board with question or concerns by calling 573-882-9500. Otherwise, please sign and date below to indicate your willingness to participate.

Participant Signature

Date 


\section{Appendix D. Interview Instrument}

\section{Relationship Genogram}

\section{Divorced Gay Fathers Study}

Refer to the participant's screening form when first beginning genogram (e.g., "I see you were married once, and that was for _ years?"). Make sure all information below is reflected on the genogram as applicable, including all previous heterosexual marriages, current gay relationship, and all children from participant's previous and current relationships including biological children, children conceived through surrogacy, stepchildren, and adopted children. Be sure to get dates for relationships (i.e., year started dating, year married/committed, year and month separated, year and month divorced), as well as the sex, age, and first name for all people on geneogram, and use names when asking questions later in interview.

\section{Previous Heterosexual Marriage}

Please tell me about when you and (ex-wife) first began dating- how would you describe your "courtship" (e.g., how met, how long before engaged, what qualities attracted to)?

Looking back, why do you think the two of you got married?

What types of things were you thinking at this time concerning your own sexuality (i.e., sexual orientation identification)?

What kinds of household roles took place when you and your wife were married (e.g., work, child care, financial management, household labor)?

\section{Dissolution of Previous Heterosexual Marriage(s)}

Tell me about your separation from (ex-spouse's name), when did you separate? (probe for details about the separation process, including who initiated, why, post-separation living arrangements)

How long do you feel you were "in the closet" to your ex-spouse (i.e., how long from time of internally identifying as gay before coming out)? Describe what you were thinking during this time (e.g., considerations for staying married, divorcing), and how/why you came out.

When was the decision to divorce made? What factors contributed to why this decision was made? What were your thoughts around this time? What do you think were (exspouse's) thoughts around this time? 
Tell me about the process of your divorce from (ex-spouse's name). How would you describe the legal divorce process?

Was your sexuality brought up in any of the divorce proceedings? How so? Did the court (e.g., judges, mediators, attorneys) know you were gay when you were divorcing or creating/modifying custody arrangements?

If not: Why was this? Is this something you wanted to conceal? Why or why not? If yes: How did this come out? Is this something you wanted to conceal? Why or why not? How, if at all, do you think your sexuality affected the court divorce/custody process?

What are the legal and physical custody arrangements for your children (also ask about child support)? How were these arrangements decided upon? What hurt or helped you and your ex work during this process? Have any of these arrangements changed since the separation/divorce, and if so, why? Would you like to make changes to your current child custody/support arrangement? (probe for influences and motivations)

\section{Post-Divorce Relationship with Children}

How often do you see your children (probe for how often at participant's home, how often he may see them in other environments, such as extracurricular events)? When your children are not at your house, can you describe the frequency and types of interaction you have with them?

What methods of communication do use in corresponding with your children? Can you describe the frequency of and types of communication used in communicating with your children?

When your children are at your house, can you describe the frequency and types of interaction they have with (ex-spouse)? What methods of communication do they use in corresponding with her?

Can you tell me what, if any, influence (ex-spouse) has on your relationship with your children? (probe for participant's thoughts on ex-spouse's motivations for this as well as examples of triangulation, if applicable)

How satisfied are you with the relationship you have with your children since the divorce? (probe for why participant answers a certain way)

Do your children know you are gay? What have you told them about this? What have their reactions been? 


\section{Post-Divorce Coparenting}

Can you describe the frequency and types of contact you have with (ex-spouse)?

What influences your interactions with (ex-spouse)? What are your motivations for working with her (or for not working with her)?

How do you make decisions about your children with (ex-spouse)?

What has it been like since your divorce interacting with schools, healthcare providers, other children's parents on issues related to your children?

In general, how do you handle coparenting arrangements, and how well do you think coparenting is working between you and (ex-spouse)?

Overall, how would you rate your coparenting relationship with your ex-wife on a scale from 1-10 (with 1 being a lower score, and 10 being a higher score)? What makes you pick this number?

\section{Post-Divorce Parenting}

In researching this project, I read articles about gay and father identities. Can you tell me about what it is like to be a gay father?

How does being a gay man affect being a father?

How does being a father affect being a gay man?

Where do you find support for being a parent?

Where do you find support, if at all, for being a parent in the gay community?

Who do you and your children interact with socially (gay families, straight families)?

\section{Current Relationship}

Tell me about your relationship with (current male partner).

Can you describe the relationship between your children and (children from relationship with current partner)? 
How do you think your relationship with (current partner) affects your relationship (i.e., coparenting interactions) with (ex-spouse)? Can you tell me about the frequency and types of contact (current partner) has with her?

In the past, have you been in relationships with other men that you feel may have affected your coparenting relationship with your ex-wife? How do you think the relationship with (former partner(s)) affected your relationship (i.e., coparenting interactions) with (exspouse)?

$* * * * * * * * * * * * * * * * * * * * * * * * * *$

Is there anything you'd like to add that we haven't talked about in this interview?

After I type up and read this interview, I may have a few follow-up questions. Would you be willing to be contacted again for follow-up questions or a future interview?

I am still recruiting fathers for this study, and any help recruiting participants is appreciated. Do you know of any gay fathers who had children in a heterosexual marriage who may wish to participate? 


\section{Appendix E. Sample Post-Interview Memo}

\section{Gentry}

Some ambivalence in this interview (said did more than average Dad but didn't articulate in practical ways, would describe mother doing more; said things worked well with ex then would later describe her as cold), and it didn't seem to flow as easily as the others did. This could because it was the first one done on campus (in "Gentry" Hall), versus over the phone or at the father's office or home. Different from the others because no influence of religion and living in Columbia may have affected wife's overall acceptance and positive coparenting. Also supports previous research on ex's trajectory after gay divorce- anger that lessens. She eventually accepted father's new partner at family events, which happened at first but still had tension involved. Also, divorce decree said he couldn't have any male partners cohabitating if kids over- even though she wasn't one of the worst ex's and even though this mandate wasn't followed over time, still an interesting comment on ex's motivations and that the courts allow these stipulations.

I asked Gentry to rate his coparenting and if coparenting has gotten better, worse, or stayed the same, and I'm going to update the interview document. I'm having difficulty digging into coparenting sometimes, as it seemed to be more "it's fine" or "it doesn't exist" type of responses. Based on how where I'm probing, it would seem that in the interview I'm most interested in the coming out and divorce process, but I need to focus more on coparenting, as I didn't know how novel this information would be in light of recent research from Benson or Bozett's research on divorced gay fathers. However, it is possible that this information is relevant to coparenting in that the contexts of the marriage, coming out process, and divorce affect how the ex-spouses relate to each other as coparents and affects coparenting quality. In my analysis I need to look at how length of marriage and time since divorce/separation may affect coparenting quality (so, will also need to classify the coparenting quality of each father).

The five interviews I've done so far seem to be taking me down a different track than what I thought may be the overall narrative when I started the project (but before I had collected data). That is, I originally wondered about a gender angle- that parents "do gender", that a traditional masculinity approach to doing fatherhood is lacking, and that when more traditionally gendered fathers divorce they may have a harder time than less traditionally gendered fathers because they are more likely to encounter/encourage maternal gatekeeping; and may have a harder time with post-divorce relationships with children. At first I wondered if divorced gay fathers would then have better quality postdivorce coparenting and father-child relationships because they may have taken a less traditional approach to fatherhood/home life because they are less traditionally gendered (i.e., living as a gay man would seem to be a pretty big rejection of traditionally masculinity), but I'm not really seeing that so far. It may still be a factor for some parents (i.e., Gentry explicitly said he was a better father because he was gay, and Tom and RR seem to convey this as well), but I don't think this will be a central narrative. 


\section{Appendix F. Sample Theoretical Memo}

\section{$\underline{\text { Kent }}$}

One of the most cooperative coparenting arrangements of all fathers- intentional coparenting from start, putting kid first, fluid and positive communication with mother, and 50/50 custody. He was not married that long (compared to other fathers, 5 years including a divorce from, and remarriage to, ex) and was younger at divorce, putting him more in the categories of Mike, Mark, and Frank versus the rest of the group. Like most of the rest of the fathers (overall), there was some level of religious influence on the decision to marry, however, this subgroup (slightly younger, married fewer years) had little to no religious influence on the divorce and coparenting, at least initially. Even though Mark is not very religious now, his ex-wife (and her husband) have used anti-gay religious ideology against him, both to the kids, "around town", and in court. Conversely, Kent and his ex worked through coparenting considerations with a Christian counselor before divorcing (it should be noted, though, that this counselor was unaware he was gay, and after he came out the counselor suggested he get resources to suppress this, so Kent left the counselor and church). For Mike and Frank there is no indication of negative religious influence on coparenting or divorce process. Interestingly, none of the fathers in this subgroup came out to their wives until after the divorce, and some indicated they probably would have stayed married (or at least that was there thinking at the time). Like William (who also didn't come out until after divorce), the driving force behind the divorce (at the time) was the ex's serial infidelities.

This is an interesting group- religion has less of an effect, overall, on coparenting, they stayed in the closet through decision to divorce, and they are slightly younger. The wives (other than Mark's) don't seem to have negative views of homosexuality (and although Mark's does, there didn't seem to be a strong history of church going and it appears she wasn't always as negative regarding his gayness- need to reread parts of his interview to see what may have changed), but the outcomes are different- two have great coparenting relationships (Kent and Mike) and two have detached coparenting (Mark, kids with him; and Frank, kid with Mom). I still think there is something to length of marriage, religiosity, other marital issues (this is too tangled of a topic to make any claims about, nothing is that black and white concerning the breakdown of a relationship), and divorce context (when, how, and if came out). But the grand narrative of religion getting in the way of coparenting is still supported.

The grand narrative is the story that I see emerging for this dissertation- how coparenting may be uniquely affected for gay fathers and what contexts affect coparenting, with a focus on religion. Although all ex's expressed feelings of anger, betrayal, and sadness (a process which has been found in other literature), over time some were able to move towards acceptance, or at least the ability to set these feelings aside to focus on good 
coparenting. Post-divorce couples in which the ex's remain angry and have bad coparenting relationships (according to the fathers' perspectives) appear to be influenced by a variety of factors, but one of the biggest contributors to the ability of divorced gay fathers and their ex's ability to coparent appears to be the influence of religion. Whether these views are deeply engrained in the mothers' belief systems and continue to be reinforced by participation in church-influenced contexts, or are used as a convenient rationale for working out their anger towards the fathers, conservative religious doctrine that views the fathers' gayness as sinful, immoral behavior has a negative effect on coparenting. (Original memo had quotes illustrating this interested here).

But when there isn't a strong anti-gay belief system present in the marriage/ex's background, or when ex's are able to revise that belief system to accommodate fathers' coming out, better coparenting relationships exist. Fathers report these relationships are not always free of frustrations, and the stories indicate the process of coparenting involves more than just religious influences, however, the absence of the negative influence of religion removes a complicating factor. Fathers who perceive less religious homophobia from their ex's appear better able to work with them on building an intentional post-divorce coparenting relationship.

I think the grand narrative is starting to emerge much clearer. Another note on Kent- At times I questioned how he told things. He described himself as very compliant and "someone who always followed the rules". Based on our interview, I wonder if he may focus on keeping some sort of pleasant equilibrium/appearance. Like William and Mark he put up with a lot from ex, including staying married while she had affairs and said she didn't want to be with him, but he did not want to divorce. He seems happy and coparenting looks great (he is able verbalize why it is good), but some things just seemed a little too glossed over. For example, I'm surprised being gay in Mid-Missouri (now and past 10 years) is so easy:

It doesn't at all. I, it's not something that's brought up. It's not something that's any different or it's, I don't wake up every day and that's not the first thing that comes to mind. I'm, I'm a father, I'm a professional, I'm a partner, and so it really doesn't factor in. It's very matter of fact piece of my life that has really had no big significant bearing. It's never caused any adversity for me, and even in my son's 12 years he's, and being in a rural area, he has yet to have an issue with any children staying the night, any other parents, any bullying, anything like that. 


\section{Appendix G. Coparenting Quality Code Table}

Coparenting Quality

Subcategories Dimensions Description

Behaviors

Uncooperative behaviors:

Undermining

Restrictive maternal

gatekeeping

Uncooperative decision-

making

Cooperative behaviors:

Prioritizing children

Joint decision-making
Badmouthing (Children reporting to father that mother called them names or spoke badly of them, fathers talking poorly of mother to children), passing messages through children to other parent, involving children in coparenting decisions (e.g., young children deciding whether or not visitation schedule will be followed)

Fathers reports of mothers withholding information on children, not following custody schedule, cutting father out of decision-making Inability to work together at all or without conflict

Motivation for working with other parent based on putting needs of children first, intentional approach to coparenting in which personal problems set aside or not seen by children, no badmouthing, concern for children drives decisions

Making decisions together or consulting/notifying other parent in decisionmaking 
Supportive

Communication

Uncooperative communication:

Avoidance of communication

Negative communication

Cooperative communication

Positive communication

Satisfaction Overall satisfaction
Handling situations as a cooperative team, supporting one another as parents, maintaining consistency, or not undermining other parent
Little to no communication due to avoidance based on resentment, past history of conflict Arguments, uncooperative interactions in which the father felt treated unfairly/aggressively

Range in frequency and depth (e.g., close friends, just coparents), but key is that there is no hesitation to communicate with ex-wife and communication described as friendly, pleasant, courteous.

Rating of coparenting relationship (1-10), description of how satisfied with coparenting relationship currently, discussion of satisfaction with coparenting overall since divorce 


\section{VITA}

Graham McCaulley received his doctorate from the Department of Human Development and Family Studies, with an emphasis in Family Studies and a Women's and Gender Studies graduate minor. He received his masters in Human Development and Family Studies and undergrad in Consumer and Family Economics, both from the University of Missouri. His research interests throughout graduate school have involved divorce and family transitions, and he has worked on studies looking at post-divorce coparenting, parental gatekeeping, financial effects of divorce, stepfamily issues, and family intervention programs. His work has been influenced by feminism, and he has also looked at the place of feminist thought in graduate education as well as gender and sexuality issues. He is employed as an Assistant Extension Professor and Personal Financial Planning State Specialist with MU Human Environmental Sciences Extension, where he works on financial education programming and outreach, with a particular interest in low-income family issues and financial literacy. He lives in Fulton, MO with his wife and two daughters. 